\title{
Algal Bioactive Metabolites against MDR Bacteria
}

\author{
R.A. Elnahas ${ }^{1}$, R. Salem ${ }^{1}$, R. Dorgham ${ }^{1}$, A. Elmorsy ${ }^{1}$, B. Elwakil ${ }^{3}$, \\ S. Khattab ${ }^{2}$ and Z. Olama ${ }^{3 *}$ \\ ${ }^{1}$ Industrial Microbiology and Applied Chemistry program, ${ }^{2}$ Chemistry Department, \\ ${ }^{3}$ Microbiology Department, Faculty of Science, Alexandria University, Egypt \\ *Corresponding author
}

\begin{tabular}{|c|c|}
\hline & A B S T R A C T \\
\hline & $\begin{array}{l}\text { Seven algal species were collected from } 7 \text { different hotspots along Alexandrian } \\
\text { Mediterranean shore; toluene and ethanol extract of U. fasciata and Enteromopha } \\
\text { intestinalis showed the maximum antibacterial although Klebsiella pneumoniae (2) }\end{array}$ \\
\hline $\begin{array}{l}\text { Ke y w or d s } \\
U . \text { fasciata, } \\
\text { Antibacterial agent, } \\
\text { Silver nanoparticles } \\
\text { and New drug. }\end{array}$ & $\begin{array}{l}\text { showed highest sensitivity towards the algal extracts while MRSA and MRSE were the } \\
\text { most resistant organisms. MIC concentration was significantly low with Gram negative } \\
\text { bacteria less than Gram positive bacteria. Time -Kill curve analysis showed that MRSA } \\
\text { was less susceptible than Ps. aeruginosa with the same extract. SEM analysis of the } \\
\text { samples showed aggregation and shrinkage in addition to leakage of the cells. LC50 was } \\
\text { determined during the period of one week and no mortality was observed. Combination }\end{array}$ \\
\hline Article Info & between algal extract and amikacin showed significant increase in the inhibition zone. \\
\hline $\begin{array}{l}\text { Accepted: } \\
\text { 04 July } 2017 \\
\text { Available Online: } \\
\text { 10 September } 2017\end{array}$ & $\begin{array}{l}U \text {. fasciata extract) + amikacin (as known antibiotic) and } U \text {. fasciata extract (as the natural } \\
\text { product). This synergy means less toxicity, less side effects and less cost. GC-MS-MS } \\
\text { analysis of the U. fasciata sample showed Acyclic and noracyclic sesterterpenoid, } \\
\text { pentacyclic triterpenoid, esters and carotenoid. Column chromatography was performed }\end{array}$ \\
\hline & $\begin{array}{l}\text { followed by antibacterial assay for the collected fractions to determine the active fraction. } \\
\text { The isolated active compound was olean- } 12 \mathrm{en}-3,15,16,21,22,28 \text {-hexol, with probability } \\
\text { only } 91.17 \% \text { so probably our isolated compound is a derivative of oleanolic acid. }\end{array}$ \\
\hline
\end{tabular}

\section{Introduction}

Human and animal pathogenic and potentially pathogenic bacteria are constantly released in the environment. Many of these organisms harbor antibiotic resistance genes which are able to spread among water and soil bacterial communities.

The introduction and progressive accumulation in the environment of antimicrobial agents, detergents, disinfectants, and residues from industrial pollution, as heavy metals, contributes to the evolution and spread of such resistant organisms in the environment (Baquero et al., 2008). Infections caused by MDR Gram negative bacilli have become a growing problem. In a recent report, the Infectious Diseases Society of America specifically addressed three categories of MDR Gram-negative bacilli, namely, extended-spectrum cephalosporin resistant Escherichia coli and Klebsiella spp., MDR Pseudomonas aeruginosa, and carbapenem-resistant Acinetobacter spp. Moreover, there are now a growing number of 
reports of cases of infections caused by Gram negative organisms for which no adequate therapeutic options exist (Giske et al., 2008).

Sometimes the use of single antibiotic does not produce the desired effective inhibitory effects and to overcome this, a combination of drugs often exercises their synergistic effect which surpasses their individual performance (Sumitra and Kalpna, 2011).

Green seaweeds have been repeatedly used as natural materials for bioactive substances over the past 20 years because of their widespread distribution and large biomass (Lingchong et al., 2014). Green seaweeds reportedly contain lipid fractions, proteins, peptides, polysaccharide, carotenoids, phenolic compounds, alkaloids, thallus, holdfast, mucilaginous, and whole plants (GuerraRivas et al., 2011; Ibñez and Cifuentes, 2013 and Kellogg and Lila, 2013). Ulva and Enteromorpha are two of the best known marine green alga genera, which widely distribute in marine, freshwater and brackish environments. $U$. fasciata, a green alga (Division: Chlorophycota; Class: Ulvophyceae; Order: Ulvales), belonging to the family Ulvaceae, commonly known as sea lettuce. Seaweed $U$. fasciata have showed antimicrobial activities against $S$. aureus and $P$. aeruginosa that are commonly found in human infections (Selvin and Lipton, 2004). Enteromorpha linza (L.) is an edible, green, broad paddle-shaped seaweed commonly seen in Asian, North European and Mediterranean coastal areas (Say et al., 1986). The seaweed is rich in various bioactive compounds, and few of its medicinal potentials have been reported (Sukatar et al., 2006 and Park et al., 2013). Enteromorpha sp. can be used for development of antimicrobial agents in pharmacology and medicine industries (Senthilkumar et al., 2014).

Algae are valuable source for various commercial products such as natural dyes and biofuels (Lee, 2008; Johansen, 2011; Borowitzka, 2013 and Fon Sing et al., 2013). Till now, for the biosynthesis of metallic NPs, different group of algae have been used such as Chlorophyceae, Phaeophyceae, Cyanophyceae, Rhodophyceae, and others (diatoms and euglenoids) (Sharma et al., 2015). The ability of algae to accumulate metals and reduce metal ions makes them the superior contender for the biosynthesis of nanoparticles. Furthermore, algae are relatively convenient and easy to handle, along with several other advantages such as synthesis at low temperature with greater energy efficiency, less toxicity, and risk to the environment. Among the biological materials, algae are called as bionanofactories because both the live and dead dried biomasses were used for the synthesis of metallic nanoparticles (Davis et al., 1998). The synthesis of silver nanoparticles using Ulva fasciata extract as a reducing agent and these nanoparticles have inhibited the growth of Xanthomonas campestris pv. malvacearum (Rajesh et al., 2012). The biomedical application of algal- synthesized NPs is significantly becoming more important due to their antibacterial, antifungal, anti-cancer, and wound healing activity. The future application is for antibiofilm, nanocomposite and biosensing (Felix et al., 2016).

The aim of the present study evaluates the antimicrobial activity of some marine algae along Alexandrian Mediterranean shore against MDR bacteria.

Test for the toxicity of the isolated antimicrobial agent.

Silver nanoparticle preparation.

Synergism between algal extract, antibiotic and silver nanoparticles to be used as a spaying agent for wound treatment.

Detection of the algal bioactive fraction. 


\section{Materials and Methods}

\section{Algae collection}

Seaweeds were collected at a depth of 1-2 m from the coast of Alexandria, Egypt ( $31^{\circ} 12^{\prime}$ $0^{\prime \prime} \mathrm{N}, 29^{\circ} 55^{\prime} 0^{\prime \prime} \mathrm{E}$ ) in October 2016 and were kindly identified by Prof. Dr. Mohamed Saad, professor of algae systematics, faculty of science, Alexandria university; as U. fasciata, $U$. prolifera, Enteromorpha intestinalis, Chaetomorpha crassa and $U$. intestinalis. Alga samples were cleaned of epiphytes and necrotic parts were removed. Then the samples were rinsed with sterile water to remove any associated debris then air- drying the algae samples.

\section{Extraction of bioactive material}

Bioactive agents were extracted followed by the method $20 \mathrm{~g}$ of each fresh and air-dried algal sample were extracted in $100 \mathrm{ml}$ of ethanol, chloroform, ethyl acetate, toluene and acetone; kept under continuous stirring for two days followed by sonification (Gonzlez del Val et al., 2001).

\section{Test microorganisms}

ATCC strains kindly provided from the U.S Naval Medical Research Unit (NMRU) in Cairo namely: Staphylococcus aureus 25923, Staphylococcus epidermidis 12228, and Pseudomonas aeruginosa 27853, Klebsiella pneumoniae 13883, Proteus mirabilis 35659, and Escherichia coli 25922 were used in the present work.

$\begin{array}{lcl}\text { Staphylococcus } & \begin{array}{c}\text { aureus } \\ \text { Staphylococcus }\end{array} & \text { (MRSA), } \\ \text { epidermidis } & \text { (MRSE), }\end{array}$
Pseudomonas aeruginosa, E. coli, Klebsiella pneumoniae, Acinetobacter sp. and Enterobacter sp. were kindly provided from Prof. Dr. Zakia's lab and kept in brain heart infusion glycerol broth at $-4{ }^{\circ} \mathrm{C}$ till testing.

\section{Antimicrobial testing}

Antimicrobial activity was evaluated using the agar disk diffusion technique in petri dishes. $25 \mu \mathrm{L}$ of each extract was loaded on sterile filter paper discs $6 \mathrm{~mm}$ in diameter. Tested microorganisms were spread on Mueller-Hinton agar plates and the discs were placed on Mueller-Hinton agar plates. After incubation for $24 \mathrm{~h}$ at $30^{\circ} \mathrm{C}$, a clear zone around a disc was evidence of antimicrobial activity. Diameters of the zones of inhibition were measured in millimeters. Each test was prepared in triplicate. Discs loaded with the solvents or the extracting agents were tested as controls.

\section{Comparison with known antibiotics}

Antibiogram of the tested microorganisms were performed following CLSI 2015 method of disk diffusion technique. The antibiotics tested were cephalothin, cefotaxime, gentamycin, cephoxitin, amikacin and imipenem.

\section{$\mathrm{MIC}$ and MBC}

Evaluation of the tested compounds in vitro antimicrobial activity was done by minimal inhibitory concentration (MIC; $\mathrm{mg} / \mathrm{mL}$ ) against Staphylococcus aureus (MRSA), Staphylococcus epidermidis (MRSE), Pseudomonas aeruginosa, E. coli, Klebsiella pneumoniae, Acinetobacter sp. and Enterobacter sp. Minimal bactericidal concentration was also evaluated. The highest extract dilution not exhibiting bacterial growth was taken as the MIC. After determining the MICs, $20 \mu \mathrm{L}$ aliquots from each well were plated onto Müller-Hinton Agar and incubated at $37^{\circ} \mathrm{C}$ for $18 \mathrm{hrs}$ (Rota et al., 2008). Following incubation, the highest dilution not exhibiting bacterial growth was recorded as the minimal bactericidal concentration (MBC). 


\section{MIC index}

The MIC index (MBC / MIC) was calculated for the antimicrobial agent to determine whether the agent is bactericidal (MBC/MIC $<4)$ or bacteriostatic (MBC / MIC >4) against the growth of MDR bacteria (Kone et al., 2004 and Chattopadhyay and Satyanshu, 2007).

\section{Time- kill curve}

A time-kill curve was assessed to the best time for the extract under test to kill the bacterial. Therefore, the selected extract that showed a bactericidal effect against the most promising bacterium under test was used, and time-kill curve was plotted. A 12-hrs culture was harvested by centrifugation. The suspension was adjusted using the McFarland standard and was then further diluted in saline $0.85 \%$ to achieve approximately $1.5 \times 10^{8}$ $\mathrm{CFU} / \mathrm{mL}$.

The selected algal extract was added to aliquots of $1 \mathrm{ml}$ Müller Hinton broth in amounts that would achieve the bactericidal concentrations for the selected bacteria followed by the addition of $1 \mathrm{~mL}$ of the inoculum. Further samples were taken from each tube to monitor growth by inoculating 10 $\mu L$ of the mixture onto Müller Hinton agar plates.

\section{Scanning electron microscope}

On the basis of MIC values and timekill curve data, MRSA and Ps. aeruginosa, was treated with the algal extract. Freshly taken samples were fixed using a universal electron microscope fixative. Electron Micrographs were taken using a Scanning Electron Microscope (JEM100 CX Joel), at the Electron Microscope Unit, Faculty of Science, Alexandria University, Egypt.

\section{Zebrafish assays for drug toxicity screening}

Zebrafish are vertebrate organisms that are of growing interest for preclinical drug discovery applications. Zebrafish embryos develop most of the major organ systems present in mammals, including the cardiovascular, nervous and digestive systems, in $<1$ week. Additional characteristics that make them advantageous for compound screening are their small size, transparency and ability to absorb compounds through the water (Rubinstein, 2006).

Females and males are kept at a ratio of 1:2 in a glass aquarium filled with charcoal filtered tap water with an oxygen saturation of more than $80 \%$. The culture conditions are $26 \pm 1$ ${ }^{\circ} \mathrm{C}$ at a 12 hour day/night light regime. The fish are fed with dry flakes twice per day. Multiple concentrations of the tested combination are tested and 7 animals are typically used for each concentration. Untreated and DMSO- treated zebra- fish are used as controls; DMSO concentration ranges from $0.1 \%$ to $0.4 \%$. LC50 was determined during the period of one week (Haldi et al., 2012).

\section{Synergism with the most promising extract}

$1.5 \times 10^{8} \mathrm{CFU} / \mathrm{mL}$ equivalent to 0.5 McFarland standard bacterial suspensions were swabbed on the top of the solidified Muller-Hinton agar plates and allowed to dry for $10 \mathrm{~min}$. The antibiotic discs were loaded with algal sterile extract and left on the surface of the inoculated agar by pressing slightly. The plates were placed at $4^{\circ} \mathrm{C}$ for 1 $\mathrm{hr}$ for compound diffusion and then incubated for $24 \mathrm{hrs}$ at $37^{\circ} \mathrm{C}$ (Abd El Aal et al., 2007), then the zones of inhibition were recorded in millimeters and the experiment was repeated three times. 


\section{Algal extract application}

\section{Silver nanoparticles formation}

The materials used for the synthesis of silver nanoparticles are $\mathrm{AgNO}_{3}$ and algal thallus extract. Exactly $17 \mathrm{mg}$ of $\mathrm{AgNO}_{3}$ was dissolved in $100 \mathrm{~mL}$ distilled water $\left(10^{-3} \mathrm{M}\right)$. Ten $\mathrm{mL}$ of algal thallus extract was added to $90 \mathrm{~mL}$ of $10^{-3} \mathrm{M} \mathrm{AgNO}_{3}$ solution for reduction of $\mathrm{Ag}+$ ions. The mixture was heated to $60^{\circ} \mathrm{C}$ for 1 hour with continuous stirring. The reduction of pure $\mathrm{Ag}^{+}$ions was monitored by measuring the UV-vis spectra of the solution. To record the size and shape of alga thallus broth reduced Ag nanoparticle, samples for Transmission Electron Microscopy (TEM) were prepared by dropcoating the Ag nanoparticle solution onto carbon- coated copper grids. The films on the TEM grids were allowed to stand for two minutes, following which the extra solution was removed using a blotting paper and the grid allow drying prior to measurement. TEM measurements were performed on a JEOL model 3010 instrument operated at an accelerating voltage at $120 \mathrm{kv}$ (Sahayara et al., 2012). Combination between the algae extract, antibiotic and silver nanoparticles were done and monitored for synergistic action between them to maximize the activity with the reduction of synthetic (antibiotic) compounds which means less toxicity, less side effects and less cost.

\section{Purification of bioactive compound(s)}

\section{Column chromatography}

The stationary phase in column chromatography is a glass column filled with silica gel (Nacalai tesque Silica gel 60, 70 130 mesh, $30 \mathrm{~g}$ ). The mobile phase is toluene. Solvent fractions are collected to separate the different compounds. Five $\mathrm{mL}$ sample was added onto the top of the column, then eluted with $150 \mathrm{~mL}$ solvent at a flow-rate of 1.5
$\mathrm{mL} / \mathrm{min}$. $5 \mathrm{~mL}$ fractions were collected immediately after the addition of solvent (Yoshihiro et al., 1998). Fractions were tested for antibacterial activity and the active fractions were analyzed by using Gas Chromatography-Mass Mass Spectrometry (GC-MS-MS).

Gas Chromatography-Mass Mass Spectrometry (GC-MS-MS)

The crude extract and the active fractions were analyzed by using a Shimadzu gas chromatograph (QP5050, NY, USA), equipped with a Rtx®-5MS column (30 $\mathrm{m} \times 0.25 \mathrm{~mm}$ ID, $0.10 \mu \mathrm{m}$ film thickness). Nitrogen was used as a carrier gas (average flow rate, $1 \mathrm{~mL} / \mathrm{min}$ ). Oven temperature program was from $110^{\circ} \mathrm{C}(2 \mathrm{~min})$ to $200^{\circ} \mathrm{C}$ at $10^{\circ} \mathrm{C} / \mathrm{min}$, then to $300^{\circ} \mathrm{C}$ at $5^{\circ} \mathrm{C} / \mathrm{min}, 9 \mathrm{~min}$ post run at $300^{\circ} \mathrm{C}$. Injector and detector [FID, Quadrupole (MS)] temperatures were $250^{\circ} \mathrm{C}$ and $280^{\circ} \mathrm{C}$, respectively. The MS working in electron impact mode at $70 \mathrm{eV}$; ion source temperature $200^{\circ} \mathrm{C}$; mass spectra data were acquired in the scan mode in $\mathrm{m} / \mathrm{z}$ range 45 450. Components relative percentages were calculated based on GC peak areas without using correction factors (Atasever-Arslan et al., 2015).

\section{Results and Discussion}

\section{Primary screening}

7 algal species were collected from 7 different hotspots along Alexandrian Mediterranean shore and they were identified as $U$. fasciata, $U$. prolifera, Enteromorpha intestinalis, Chaetomorpha crassa and $U$. intestinalis from the east to the west of Alexandrian Mediterranean shore. Results revealed that toluene and ethanol extracts of algae 2 ( $U$. fasciata) and algae 4 (Enteromorpha intestinalis) showed the maximum antibacterial activity against the ATCC organisms (Table 1; Figures 1, 2 and 3). 


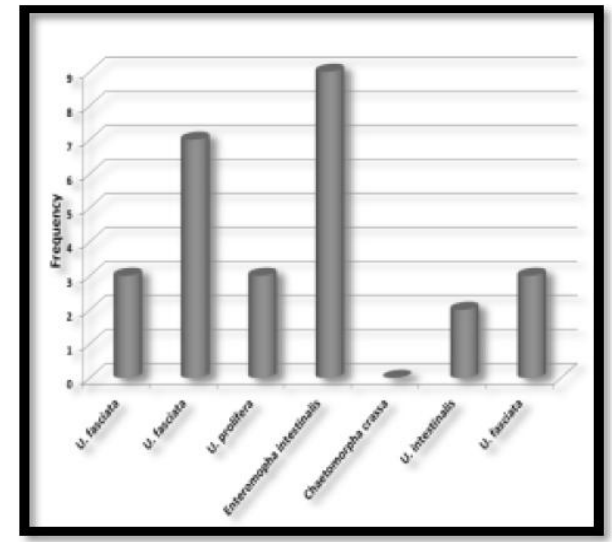

Fig.1 Antibacterial activity of the collected algae using different solvents

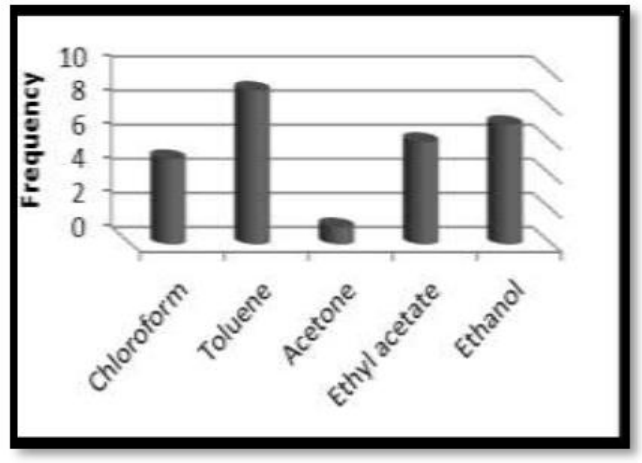

Fig.2 Antibacterial activity of the algal extracts using different solvents

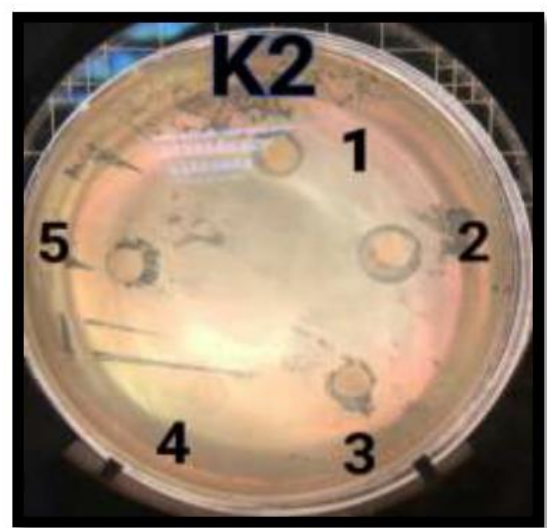

Fig.3 The effect of $U$. fasciata bioactive extract against ATCC bacteria using different solvents

While there were 3 samples identified as $U$. fasciata only one showed promising activity as several ecological factors influence the growth and development of marine algae.
Seasonal changes produce a wide range of temperatures and atmospheric conditions that affect algae production in many ways. Other ecological factors include substrate, storms, currents, and people. Humans collecting seaweed for personal use or harvesting have destroyed many productive seaweed beds. All these factors affect the quantity of the bioactive material expressed by the algae and that's why one can notice the difference in activity among the same species (Fig. 4).

\section{Antimicrobial testing against MDR bacteria}

Klebsiella pneumoniae (2) showed highest sensitivity towards the algal extracts while MRSA and MRSE were the most resistant organisms as shown in figures 5 and 7 . Toluene extracts of $U$. fasciata and Enteromorpha intestinalis showed the maximum activity against the tested bacteria (Figure 6 and Table 2).

Priyadharshini et al., (2011) stated that $U$. fasciata was screened for antimicrobial activity. Methanol, butanol and aqueous extracts were tested against selected fish pathogens, Aeromonas hydrophila, Pseudomonas fluorescens, Proteus sp. Vibrio alginolyticus ( $V$. alginolyticus) and Enterobacter sp. and fungal pathogens namely Rhizopus sp., Aspergillus flavus, Aspergillus sp., Aspergillus niger and Candida sp. Maximum inhibition zone was observed against $V$. alginolyticus and the minimum against Enterobacter sp., respectively. U. fasciata showed poor activity against the fungal pathogens. The variation in antibacterial activity may be due to the method of extraction, solvents and seasonal variation. 
Table.1 Antibacterial activity of the algal extracts against ATCC

\begin{tabular}{|c|c|c|c|c|c|c|}
\hline $\begin{array}{l}\text { Algal/Ext. } \\
\text { solvent }\end{array}$ & $\begin{array}{c}\text { St. } \\
\text { aureus } \\
25923\end{array}$ & $\begin{array}{c}\text { St. } \\
\text { epidermidis } \\
12228\end{array}$ & $\begin{array}{c}\text { Ps. } \\
\text { aeruginosa } \\
27853\end{array}$ & $\begin{array}{c}K . \\
\text { pneumoniae } \\
13883\end{array}$ & $\begin{array}{c}\text { Pr: } \\
\text { mirabilis } \\
35659\end{array}$ & $\begin{array}{r}\text { E. coli } \\
25922\end{array}$ \\
\hline U. fasciata $1 \mathrm{~A}$ & - & + & - & - & - & - \\
\hline B & - & - & - & - & - & - \\
\hline C & - & - & - & - & - & - \\
\hline D & - & + & - & - & - & - \\
\hline $\mathbf{E}$ & - & + & - & - & - & - \\
\hline U. fasciata 2 A & - & - & + & + & - & \\
\hline B & - & - & + & + & - & + \\
\hline C & - & - & - & - & - & - \\
\hline D & + & - & - & + & - & - \\
\hline $\mathbf{E}$ & - & + & - & - & - & - \\
\hline U. prolifera $\mathrm{A}$ & - & - & - & - & - & + \\
\hline B & - & - & - & - & - & - \\
\hline $\mathrm{C}$ & - & - & - & - & - & - \\
\hline D & - & - & - & - & - & - \\
\hline $\mathbf{E}$ & - & + & - & - & - & + \\
\hline En. intestinalis A & - & - & - & + & - & - \\
\hline B & + & - & - & + & + & + \\
\hline C & - & - & - & + & - & - \\
\hline D & - & - & - & - & + & - \\
\hline $\mathbf{E}$ & - & + & - & + & - & - \\
\hline Chaetomo. A & - & - & - & - & - & - \\
\hline B & - & - & - & - & - & - \\
\hline C & - & - & - & - & - & - \\
\hline D & - & - & - & - & - & - \\
\hline $\mathbf{E}$ & - & - & - & - & - & - \\
\hline U. intestinalis A & - & - & - & - & - & - \\
\hline B & - & - & - & - & + & - \\
\hline C & - & - & - & - & - & - \\
\hline D & - & - & - & - & + & - \\
\hline $\mathbf{E}$ & - & - & - & - & - & - \\
\hline U. fasciata $3 \mathrm{~A}$ & - & - & - & - & - & - \\
\hline B & - & - & - & - & - & + \\
\hline C & & & & & - & - \\
\hline D & - & - & - & - & - & + \\
\hline $\mathbf{E}$ & - & - & + & - & - & - \\
\hline
\end{tabular}

A: Chloroform; B: Toluene; C: Acetone; D: Ethyl acetate; E: Ethano1

Table.2 Antibacterial activity of the algal extracts against MDR

\begin{tabular}{|l|c|c|c|c|}
\hline \multicolumn{5}{|c|}{ Inhibition zone Diameter (mm) } \\
\hline Algal/Ext. solvent & U.f2/Eth & U.f2/Tol & En/Eth & En/Tol \\
\hline Ps. aeruginosa & 7 & 6 & 7 & 6 \\
\hline E. coli & 6 & 7 & 6 & 7 \\
\hline K. pneumoniae 1 & 9 & 11 & 6 & 12 \\
\hline K. pneumoniae 2 & 6 & 19 & 6 & 7 \\
\hline K. pneumoniae 3 & 6 & 9 & 6 & 7 \\
\hline K. pneumoniae 4 & 6 & 13 & 6 & 7 \\
\hline Acinetobacter & 7 & 7 & 7 & 8 \\
\hline Enterobacter & 6 & 10 & 6 & 6 \\
\hline MRSE & 6 & 6 & 6 & 6 \\
\hline MRSA 1 & 6 & 6 & 6 & 6 \\
\hline MRSA 2 & 6 & 6 & 6 & 7 \\
\hline MRSA 3 & 6 & 10 & 6 & 8 \\
\hline
\end{tabular}


Table.3 Inhibition zone of the tested antibiotics against the clinical isolates

\begin{tabular}{|l|c|c|c|c|c|c|}
\hline \multicolumn{7}{|c|}{ Inhibition zone Diameter (mm) } \\
\hline Sample/Antibiotic & KF & CTX & IPM & CN & FOX & AK \\
\hline Ps. aeruginosa & 6 & 6 & 13 & 6 & 6 & 17 \\
\hline E. coli & 6 & 6 & 28 & 6 & 18 & 20 \\
\hline K. pneumoniae 1 & 6 & 6 & 17 & 6 & 6 & 15 \\
\hline K. pneumoniae 2 & 6 & 6 & 19 & 22 & 24 & 23 \\
\hline K. pneumoniae 3 & 6 & 6 & 16 & 11 & 6 & 18 \\
\hline K. pneumoniae 4 & 6 & 6 & 25 & 6 & 6 & 17 \\
\hline Acinetobacter & 6 & 6 & 15 & 6 & 6 & 18 \\
\hline Enterobacter & 6 & 6 & 9 & 6 & 6 & 19 \\
\hline MRSE & 25 & 13 & 44 & 25 & 30 & 27 \\
\hline MRSA 1 & 6 & 14 & 25 & 6 & 11 & 13 \\
\hline MRSA 2 & 6 & 6 & 25 & 6 & 13 & 13 \\
\hline MRSA 3 & 6 & 6 & 20 & 6 & 20 & 20 \\
\hline
\end{tabular}

KF: Cephalothin; CTX: Cefotaxime; IPM: Imipenem; CN: Gentamycin; FOX: Cefoxitin; AK: Amikacin

Fig.4 Antibacterial activity of the most promising algal extracts

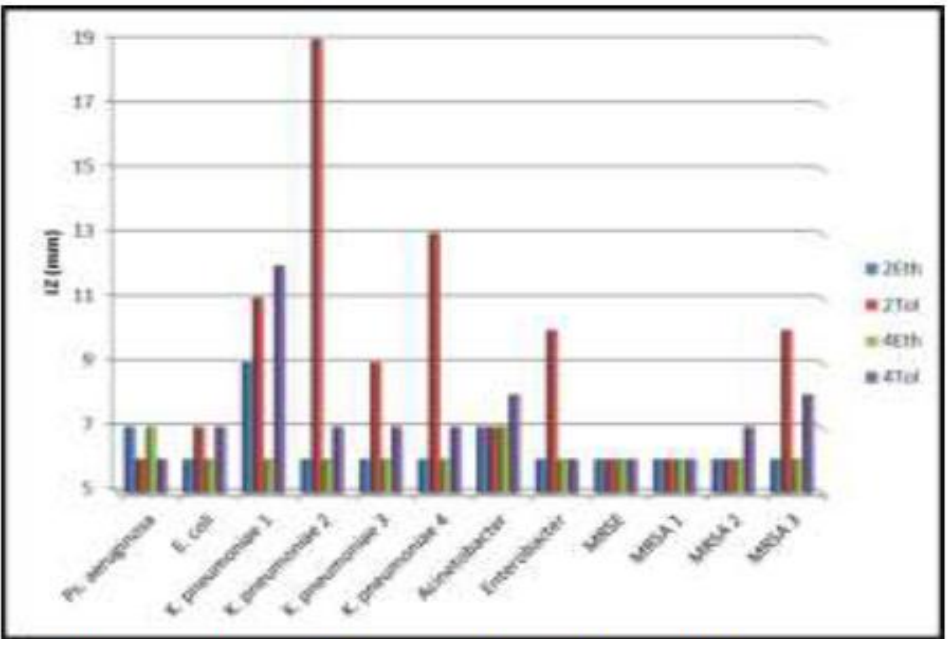


Fig.5 Antibacterial activity of the most promising solvent

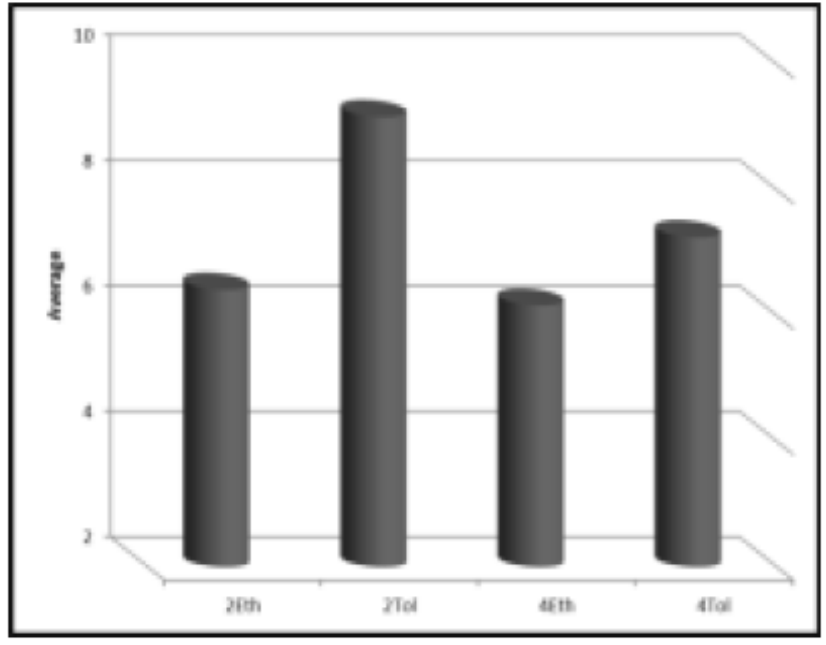

Fig.6 Antibiogram of the algal extract against MDR bacteria

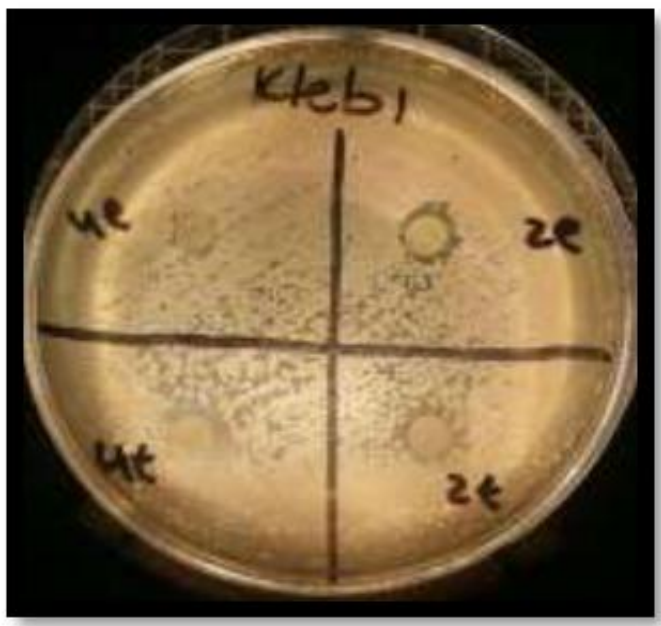

Fig.7 Resistance pattern of the tested bacteria against the algal extracts

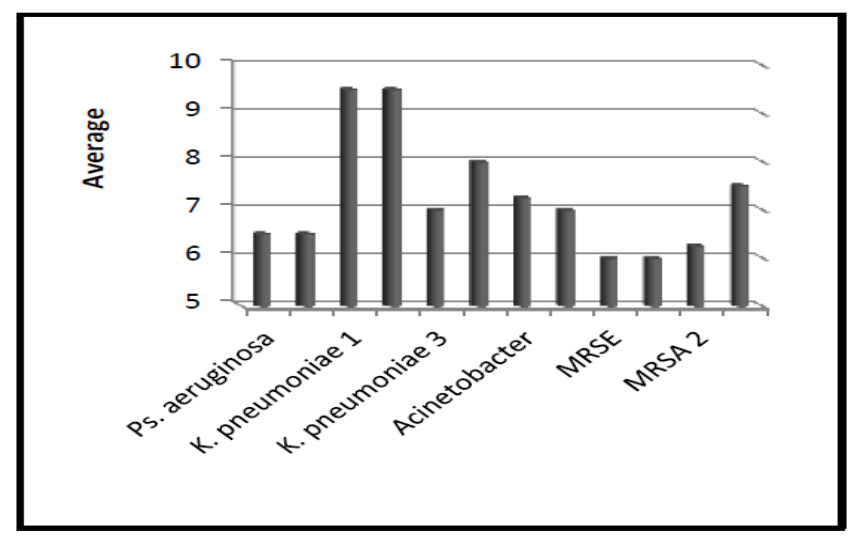




\section{Comparison with known antibiotics}

As shown in table 3 and figures 9 and 11, MRSE was the most sensitive organism while Ps. aeruginosa and Enterobacter sp. were the most resistant organisms toward the tested antibiotics (Fig. 8).

Imipenem has the highest average inhibition zone between the tested antibiotics while Cephalothin and cefotaxime were the lowest (as represented in Figure 10).
Chandrasekaran et al., (2014) found that the clinical isolates of $E$. coli were sensitive to all the antibiotics tested and resistant to CFM, AMP, CAZ and GEN. The clinical isolates of $K$. pneumoniae were resistant to all the antibiotics tested and sensitive to GEN, S, TE, $\mathrm{AK}$ and $\mathrm{E}$. The clinical isolates of $P$. aeruginosa were sensitive to all the antibiotics tested and resistant to CFM, AMP, $\mathrm{CAZ}$ and $\mathrm{E}$.

Fig.8 Resistance pattern of the tested bacteria against the antibiotics

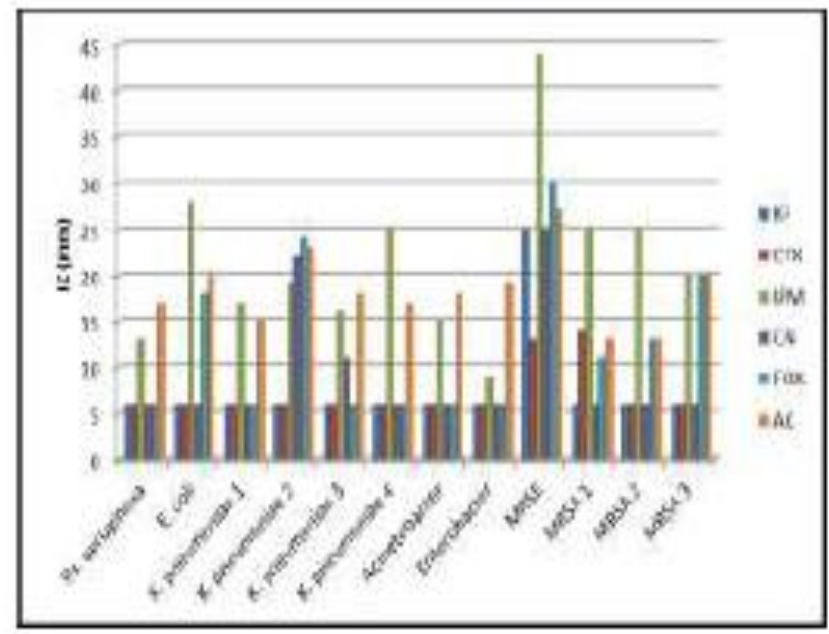

Fig.9 Average inhibition zone of the tested antibiotics

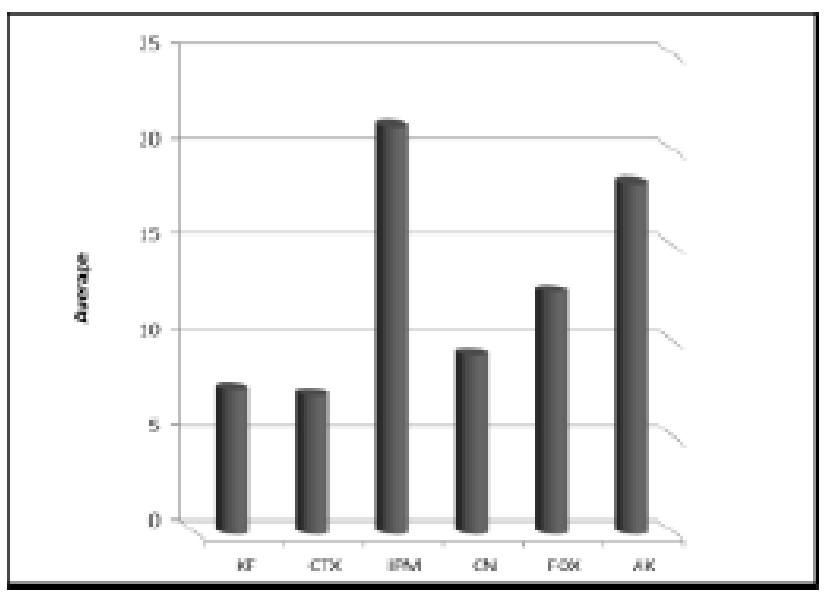


Fig.10 Average of resistance between the tested bacteria and the antibiotics

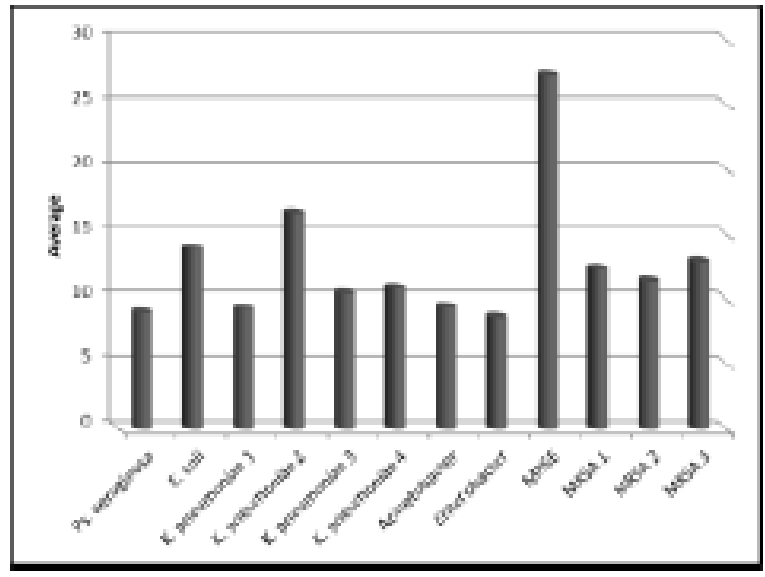

Fig.11 Antibiogram of the antibiotics against Klebsiella pneumoniae

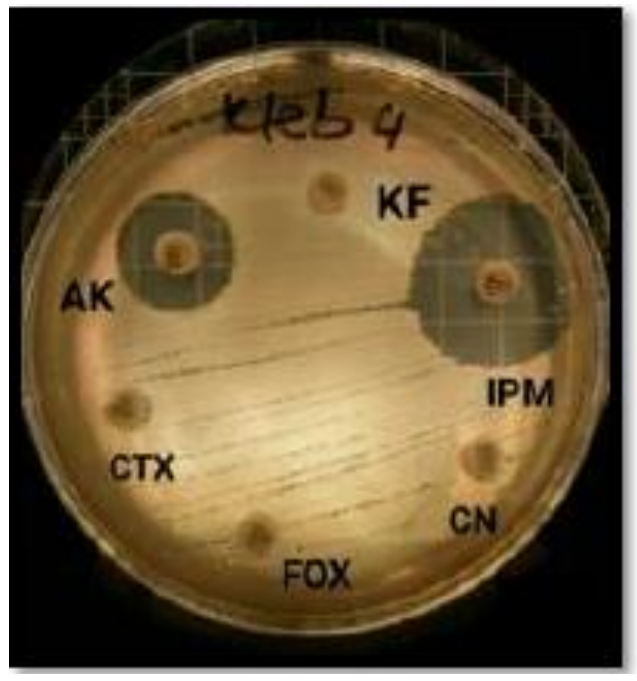

\section{MIC and MBC}

U. fasciata and Enteromorpha intestinalis showed significantly low MIC with Gram negative bacteria less than Gram positive bacteria as illustrated in table 4. Maximum activity $(12.5 \mu \mathrm{g} / \mathrm{mL})$ was shown by Enteromorpha intestinalis (toluene extract) against $K$. pneumoniae 1 and $U$. fasciata (toluene extract) against $K$. pneumoniae 4.

Chandrasekaran et al., (2014) found that the highest mean of zone inhibition $(15.0 \mathrm{~mm})$ and lowest MIC $(125 \mu \mathrm{g} / \mathrm{mL})$ and MBC (250 $\mu \mathrm{g} / \mathrm{mL})$ values were observed with ethyl acetate extract of $U$. fasciata against $B$. subtilis. This may indicate that the extraction method had definite effects on the isolation of bioactive principles due to the efficiency of the solvent for the extraction of the effective components.

\section{Time- Kill curve}

Time-Kill curve analysis showed that MRSA treated with $U$. fasciata toluene extract were less susceptible than Ps. aeruginosa with the same extract. Results in figure 12 showed that upon using $U$. fasciata toluene extract, the bacterial growth for the tested organisms 
sharply decreased after 6 and 8 hours to reach zero value at $10 \mathrm{hrs}$. On the other hand MRSA treated with Enteromorpha intestinalis (toluene extract) which reaches zero value after 12 hrs.

\section{Scanning electron microscope}

SEM analysis of the samples was done to examine the morphological changes that occurred to the tested organisms after treatment with the promising extracts. SEM of the Ps. aeruginosa cells (as an example of Gram negative bacteria) after treatment with the algal extracts showed aggregation and shrinkage in addition to leakage of the cells was observed compared to untreated cells (control) (Figure 13). In case of MRSA (as an example of Gram positive bacteria) breaking down of the cell wall, degradation of cell organelles, and changes in cell permeability have been noted to occur as the most significant cellular alterations after exposure to the selected algal extracts. Taskin et al., (2001) reported similar observations, indicating that Grampositive bacteria more susceptible to the algal extract due to the differences in their cell wall structure and their composition (Paz et al., 1995). The resistance of Gram negative bacteria towards antibacterial substances is related to the hydrophobic surface of their outer membrane which is rich in lipopolysaccharides molecules, presenting a barrier to the penetration of numerous antibiotic molecules. The membrane is also associated with the enzymes in the periplasmic space which are capable of breaking down the molecules introduced from outside (Shan et al., 2007).

\section{Zebra fish assays for drug toxicity screening}

In the present work the evaluation of the $U$. fasciata extract toxicity was done by testing multiple concentrations of the tested extract (ranging from MIC value and its multiples) are tested and 7 animals are typically used for each concentration. LC50 was determined during the period of one week and no mortality was observed during the test period as shown in figure 14-16.

\section{The combined action between the antibiotic and algal extract}

Amikacin and gentamycin were tested alone one at a time against the bacteria under test and then in combination with the most promising algal extracts which showed significant increase in the inhibition zone in the case of $U$. fasciata toluene extract plus amikacin (Figure 17). Synergistic effect between $U$. fasciata (Toluene extract) and amikacin was represented in the treatment of $P$ s. aeruginosa, $K$. pneumoniae 1 and 4 and MRSA 1 and 2 (Table 5).

Synergy is often associated with the cliché $\mathrm{t} h$ a $t$ the whole is greater than the sum of the parts, an idea which emerged at the time of Aristotle (350 AC), and is described in his work Metaphysics. But synergy is not always greater than the sum of the parts, in some cases; the synergic result is merely different. Synergism is defined as a positive interaction created when two agents are combined and together they exert an inhibitory effect (on the targeted organisms) that is greater than the sum of their individual effects. Antagonism occurs when the effect of two drugs together is less than the effect of either alone and indifference when no effect is exhibited. In rational drug therapy, the concurrent administration of two or more drugs is often essential and sometimes mandatory in order to achieve the desired therapeutic goal or to treat coexisting diseases.

\section{Silver nanoparticles}

The reduction of pure Ag+ ions was monitored by measuring the UV-vis spectra of the solution. The prepared aqueous solution 
of $\mathrm{Ag}$ nanoparticles showed an absorption band at $391 \mathrm{~nm}$ as shown in figure 18, which is a typical absorption band of spherical $\mathrm{Ag}$ nanoparticles. Shape and size distribution of the synthesized Ag nanoparticles were characterized by transmission electron microscopic (TEM) study which is illustrated in figure 19. The analysis showed size distribution ranging from 37.9 to $175 \mathrm{~nm}$ with aggregated morphological feature. However, to use $\mathrm{Ag}$ in various fields against microorganisms, it is essential to prepare the Ag with cost-effective methods and to know the mechanism of the antimicrobial effect. However, it is important to enhance the antimicrobial effect. In the present study evaluation of the silver nanoparticles combined with $U$. fasciata extract and amikacin was done (as shown in figures 20 and 21 and Table 6). Synergistic action was noticed between the silver nanoparticles (green synthesized by the $U$. fasciata extract) + amikacin (as known antibiotic) and $U$. fasciata extract (as the natural product). This synergy means less toxicity, less side effects and less cost.

Fig.12 SEM for the treated and non-treated samples. Alg.2: U. fasciata and Alg.4: Enteromorpha intestinalis

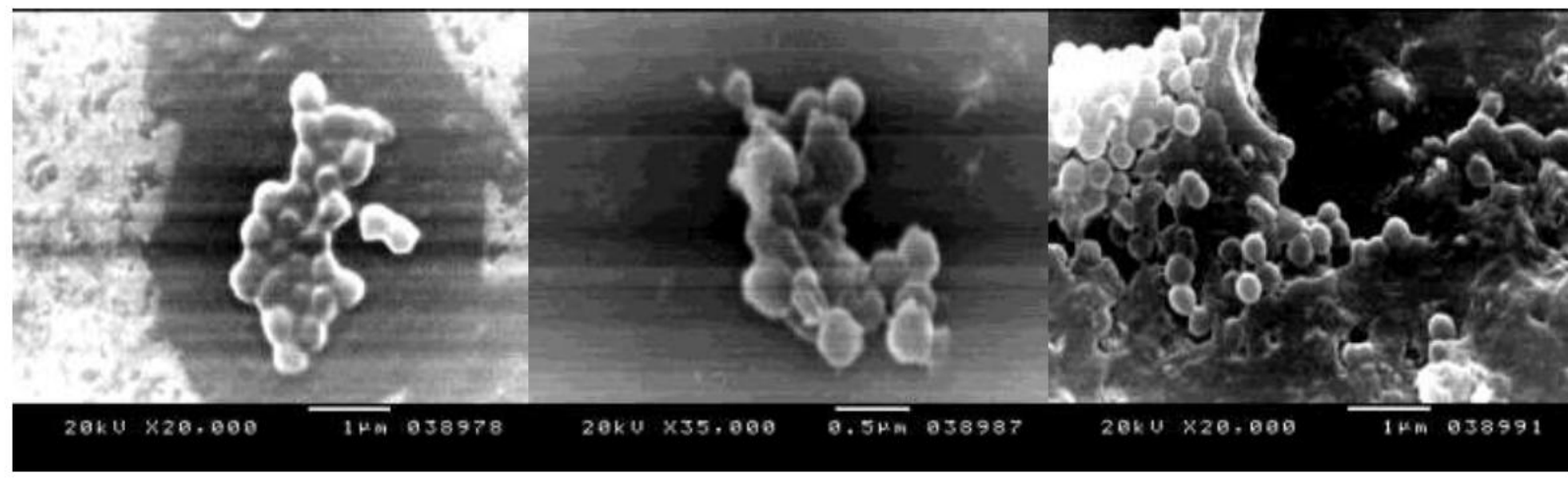

Staph.

Staph. 2Tol

Staph. 4Tol

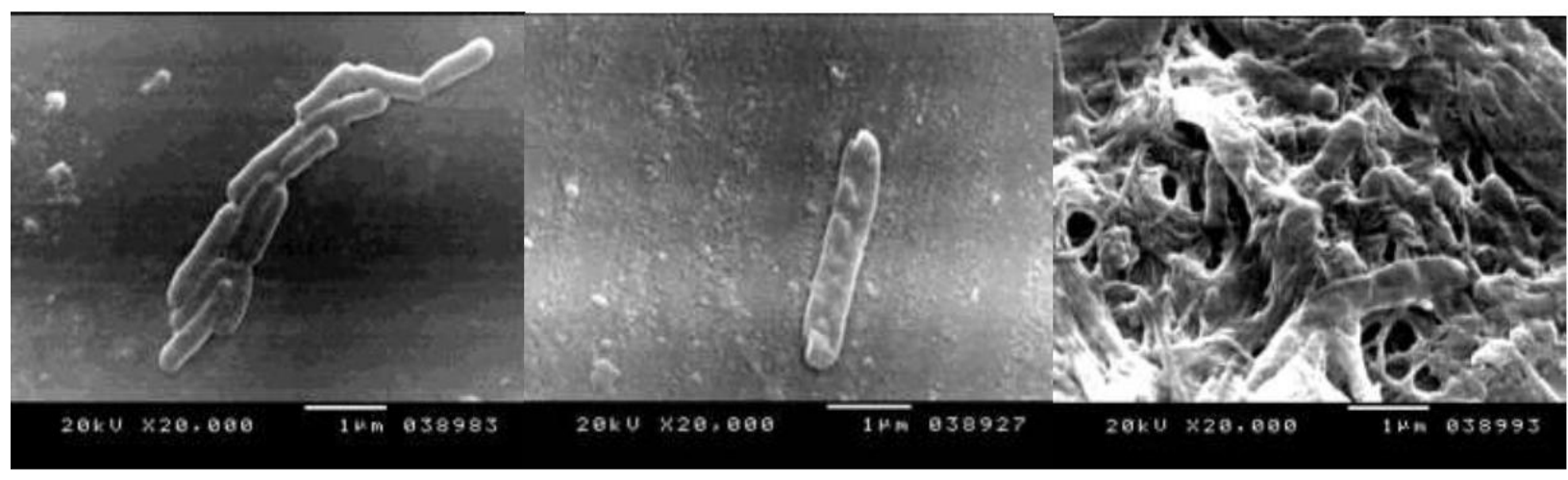

Pseudomonas

pseudomonas 2Tol

pseudomonas 4Tol 
Fig.13 Mortality rate of Zebra fish

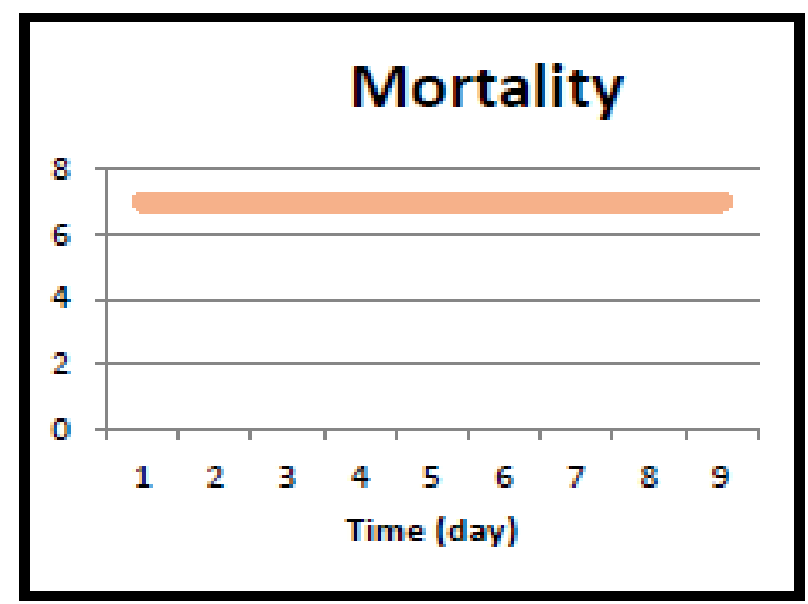

Fig.14 Alg.2: U. fasciata and Alg.4: Enteromorpha intestinalis

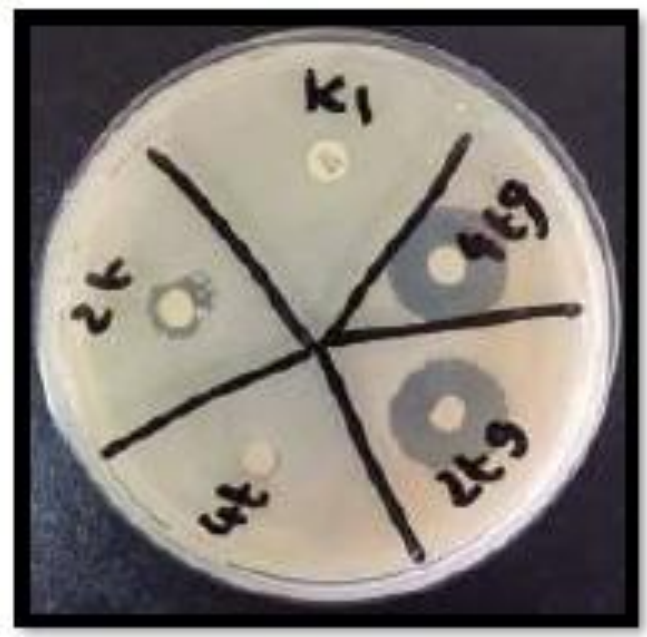

Fig.15 Alg.2: U. fasciata and Alg.4: Enteromorpha intestinalis

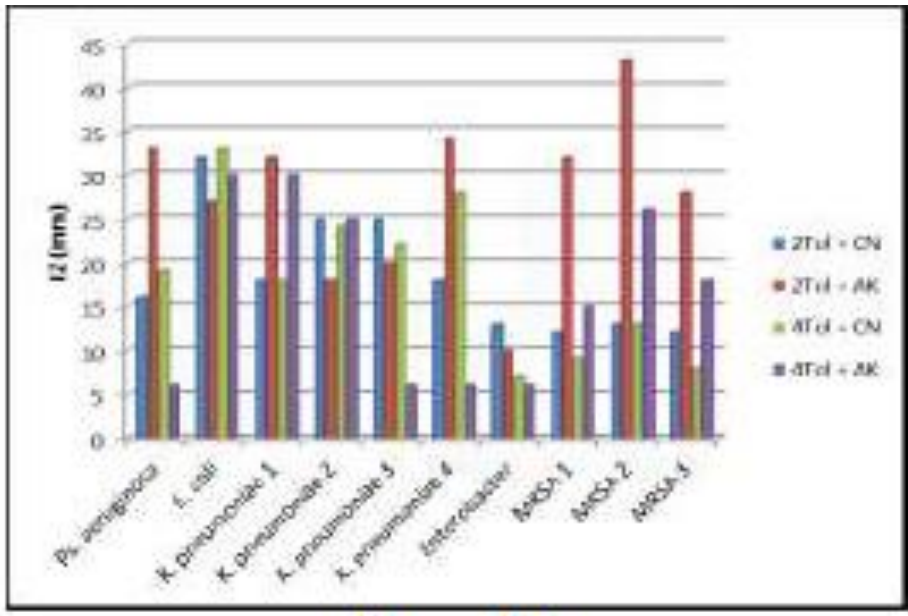


Fig.16 Alg.2: U. fasciata and Alg.4: Enteromorpha intestinalis

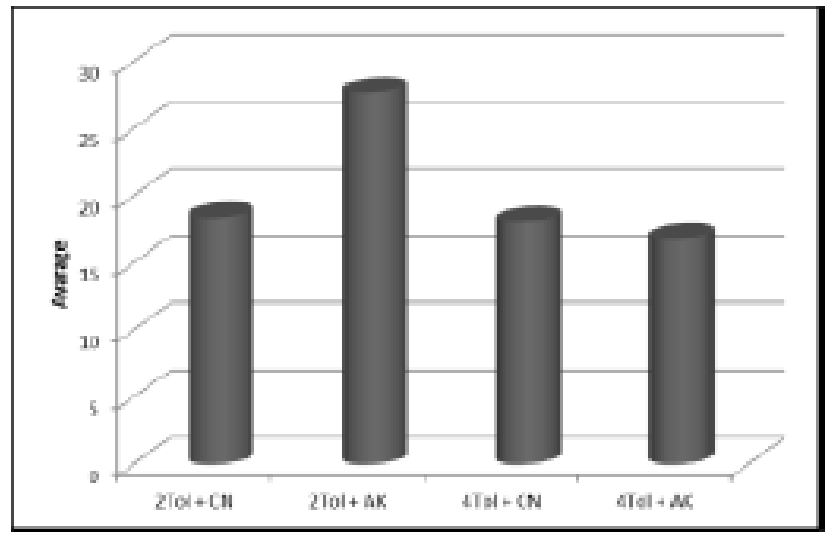

Fig.17 UV-vis of the Ag+ ions

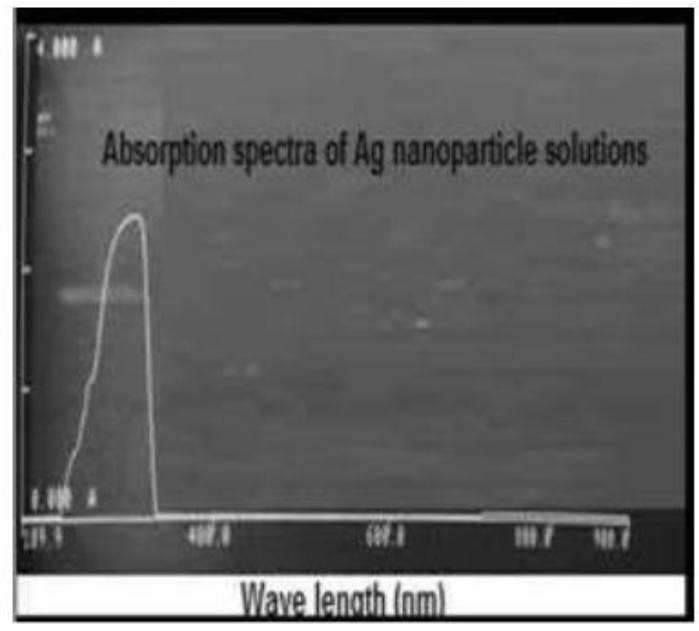

Fig.18 TEM of Ag+ ions synthesized by the algae extract

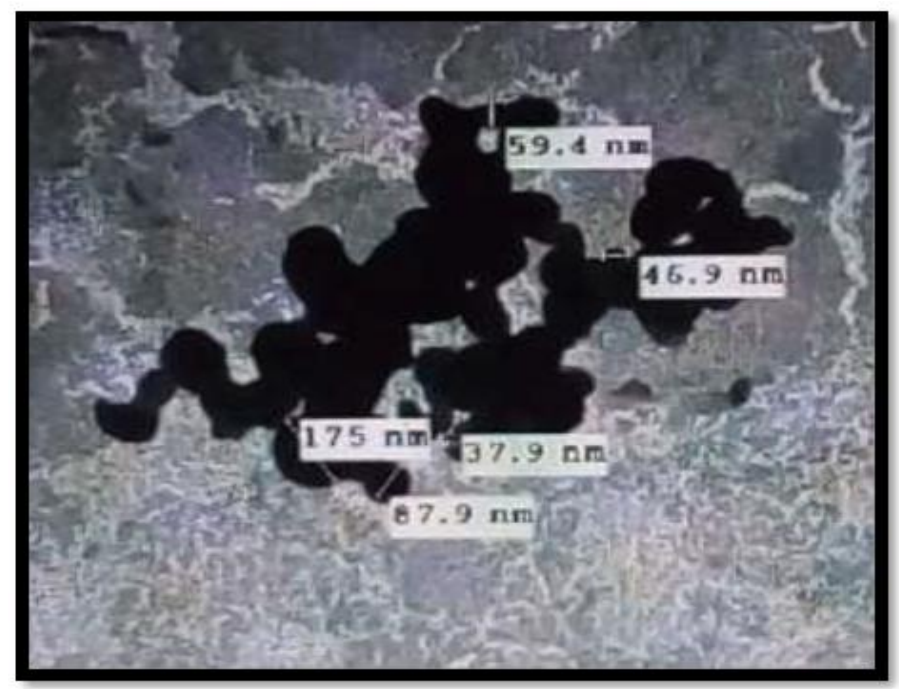


Fig.19 Antibacterial activity of the nanoparticles and the final formula

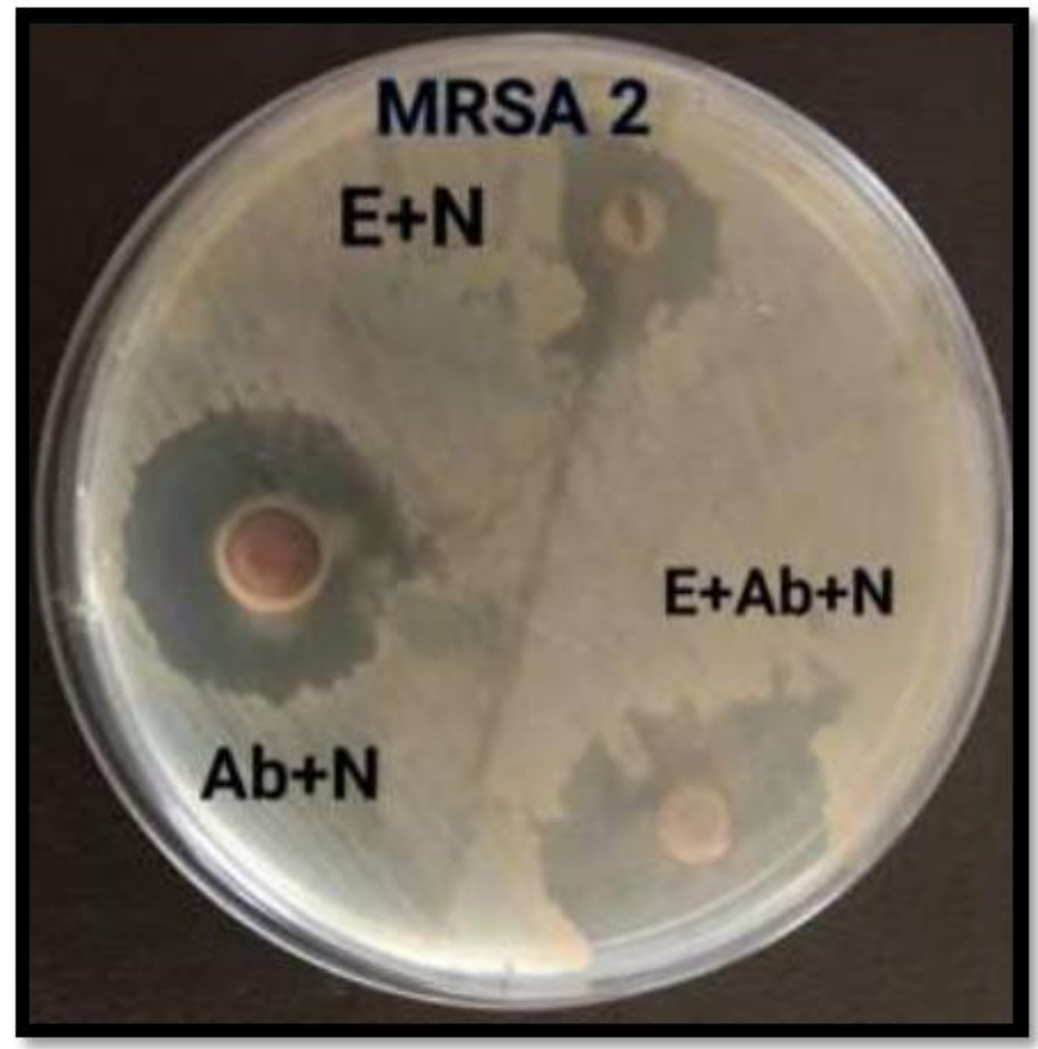

Fig.20 Synergy activity of silver nanoparticles combined with $U$. fasciata extract and amikacin

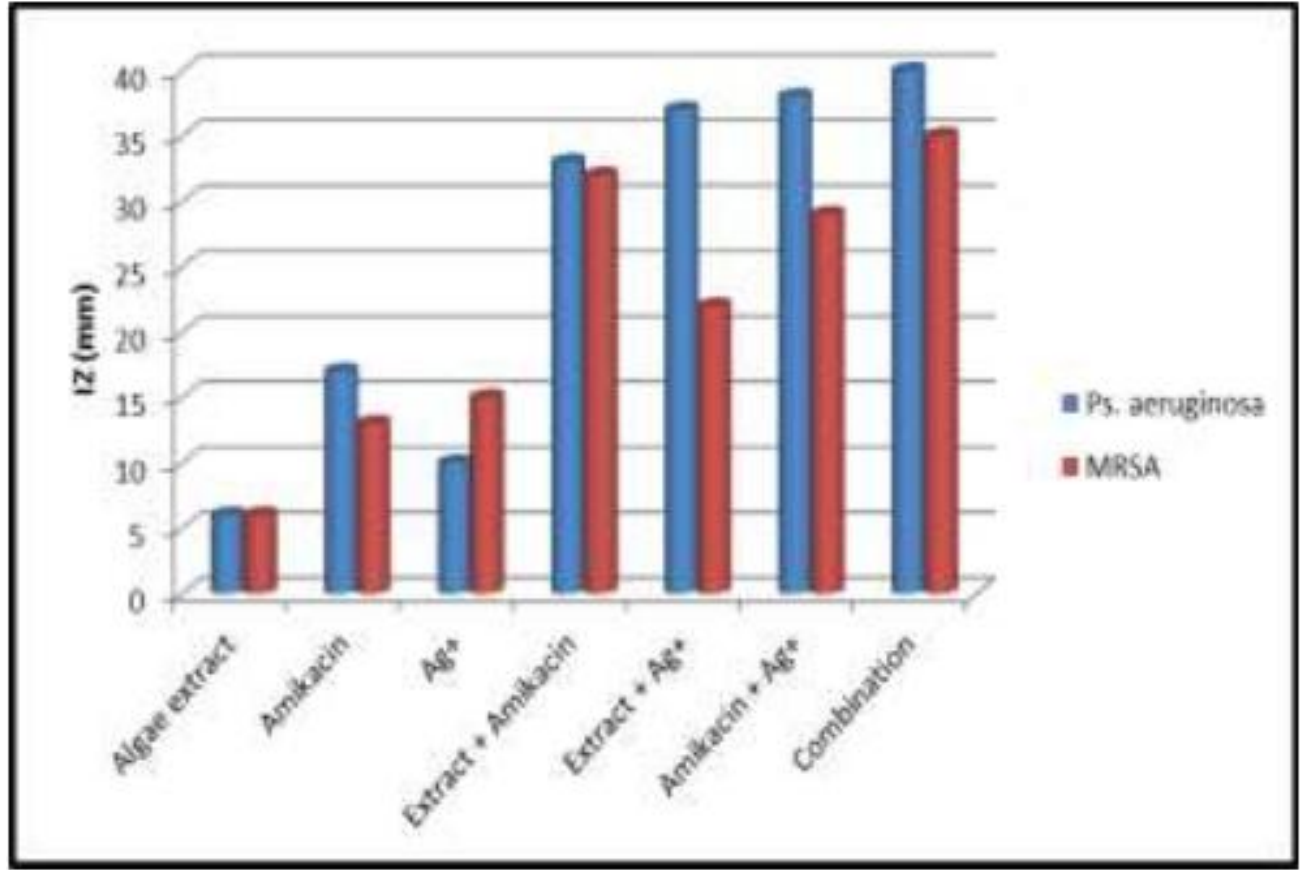


Fig.21 GC chromatogram of the crude $U$. fasciata toluene extract

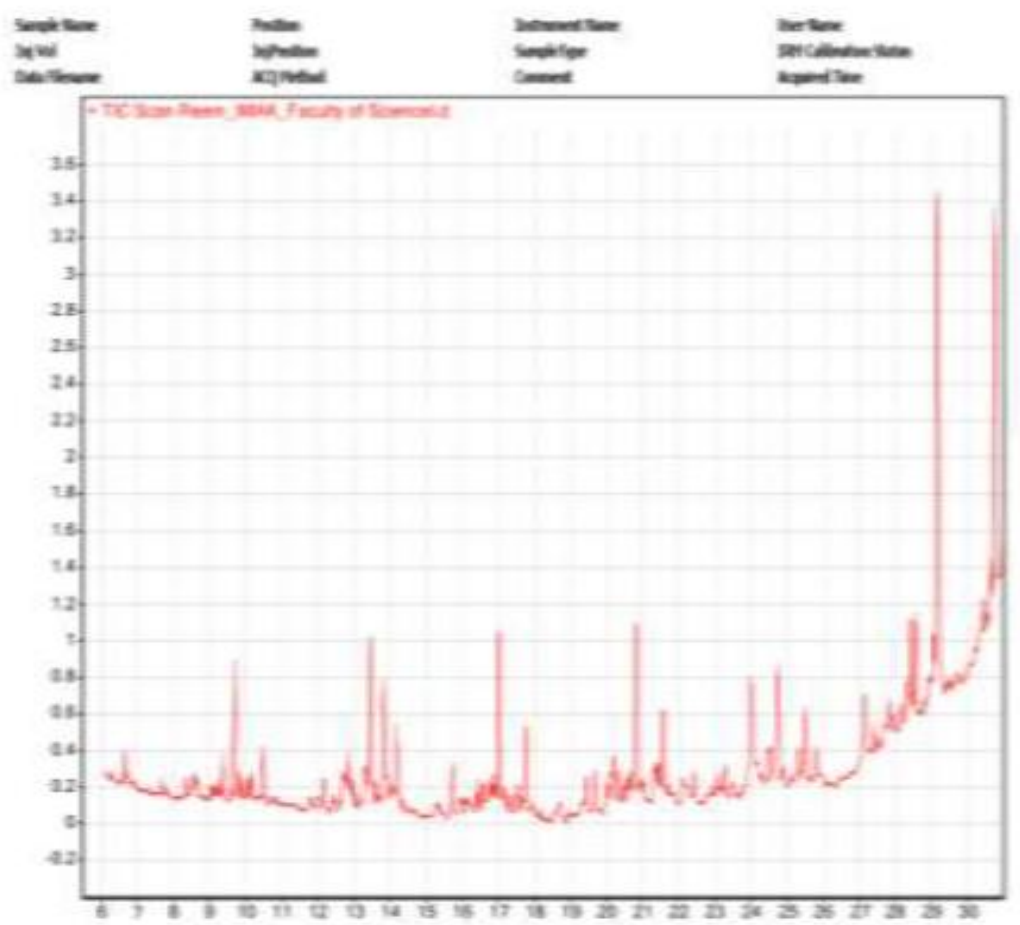

Fig.22 Antibacterial activity of the active fraction

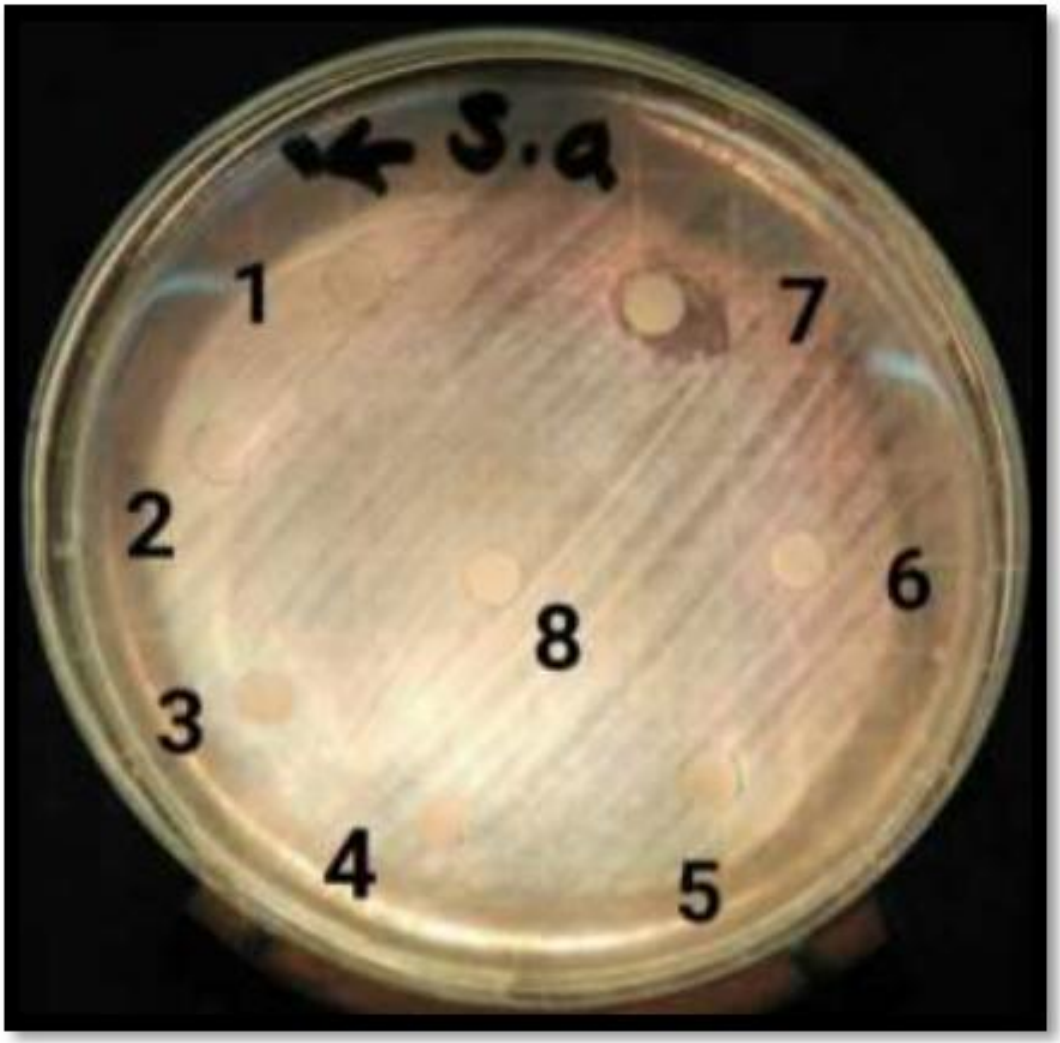


Fig.23 RT 30.4, probable compound d olean-12-en-3, 15, 16, 21, 22, 28-hexol

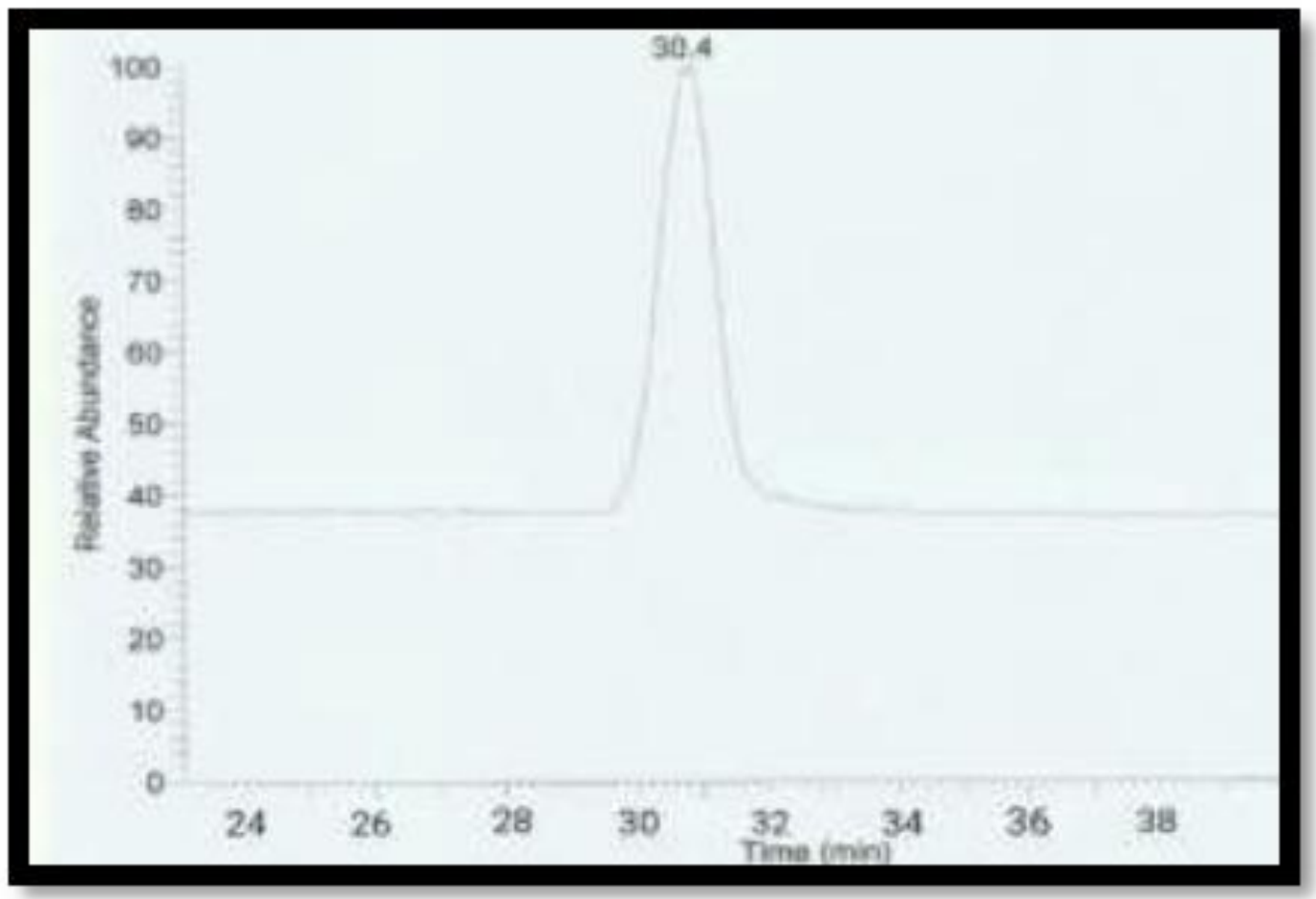

Fig.24 Structure of olean-12-en-3, 15, 16, 21, 22, 28-hexol

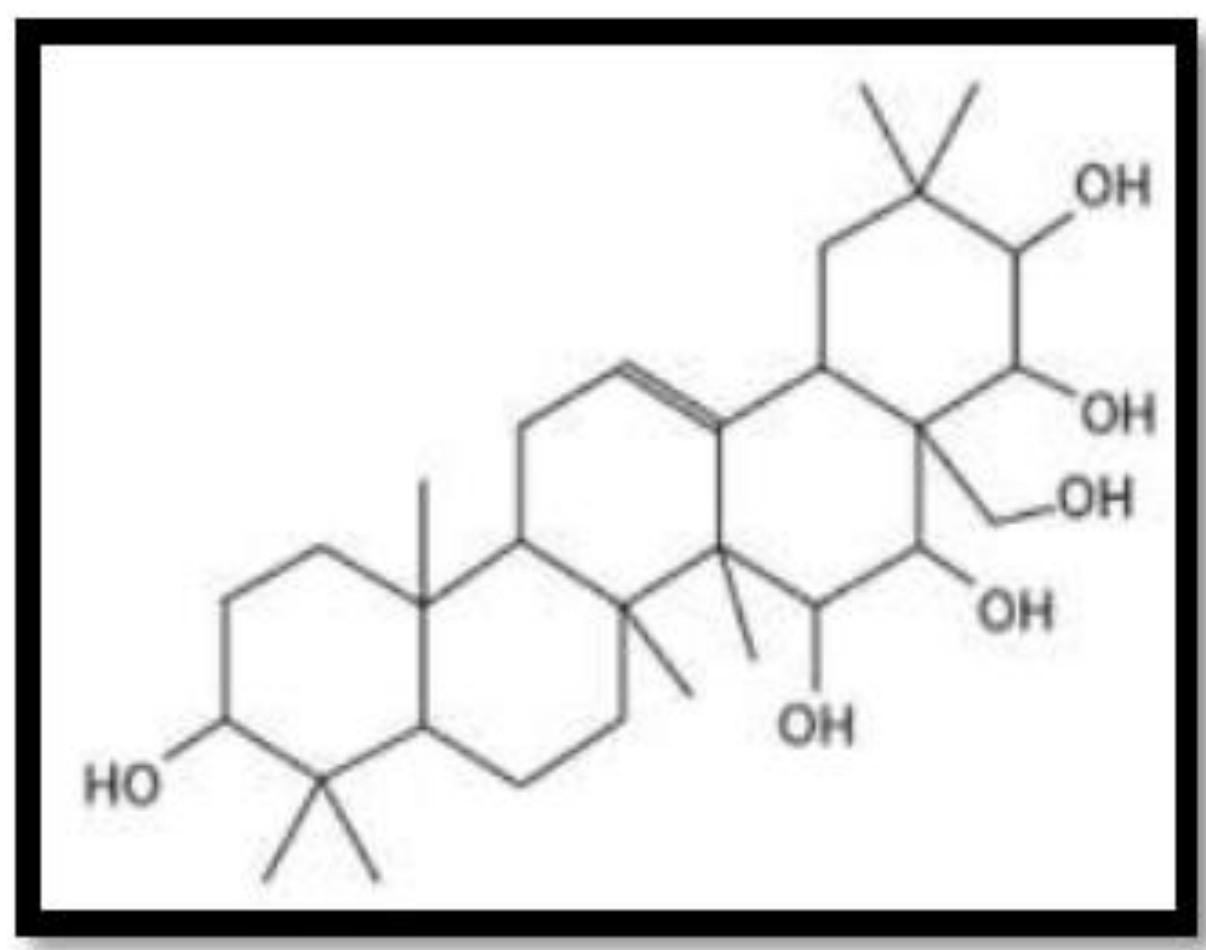


Table.4 MIC values of the most promising algal extracts $(\mu \mathrm{g} / \mathrm{mL})$

\begin{tabular}{lllll}
\hline Algal/Ext. & U.f2/Eth & U.f2/Tol & En/Eth & En/Tol \\
\hline Ps. aeruginosa & 125 & 250 & 125 & 250 \\
\hline E. coli & 250 & 125 & 250 & 250 \\
$K$. pneumoniae 1 & 62.5 & 31.25 & 125 & 15.6 \\
$K$ pneumoniae 2 & 250 & 31.25 & 250 & 125 \\
$K$ pneumoniae 3 & 250 & 31.25 & 250 & 125 \\
$K$. pneumoniae 4 & 250 & 15.6 & 250 & 125 \\
Acinetobacter & 125 & 125 & 125 & 250 \\
Enterobacter & 250 & 31.25 & 250 & 125 \\
MRSE & 250 & 250 & 250 & 250 \\
MRSA 1 & 250 & 250 & 250 & 250 \\
MRSA 2 & 250 & 125 & 250 & 250 \\
MRSA 3 & 250 & 31.25 & 250 & 125 \\
\hline
\end{tabular}

Table.5 Synergism with the most promising extract

\begin{tabular}{|c|c|c|c|c|c|c|c|c|}
\hline \multicolumn{9}{|c|}{ Inhibition zone (mm) } \\
\hline Organism/Combination & $\begin{array}{c}\mathbf{2 T o l}+ \\
\mathbf{C N}\end{array}$ & $\begin{array}{c}\text { Com. } \\
\text { action }\end{array}$ & $\begin{array}{c}\mathbf{2 T o l}+ \\
\mathbf{A K}\end{array}$ & $\begin{array}{c}\text { Com. } \\
\text { action }\end{array}$ & $\begin{array}{c}\mathbf{4 T o l}+ \\
\mathbf{C N}\end{array}$ & $\begin{array}{c}\text { Com. } \\
\text { action }\end{array}$ & $\begin{array}{c}\mathbf{4 T o l}+ \\
\text { AK }\end{array}$ & $\begin{array}{c}\text { Com. } \\
\text { action }\end{array}$ \\
\hline Ps. aeruginosa & 16 & Synergy & 33 & Synergy & 19 & Synergy & 6 & Antagony \\
\hline E. coli & 32 & Synergy & 27 & Indifferent & 33 & Synergy & 30 & Synergy \\
\hline K. pneumoniae 1 & 18 & Synergy & 32 & Synergy & 18 & Indifferent & 30 & Synergy \\
\hline K. pneumoniae 2 & 25 & Antagony & 18 & Antagony & 24 & Antagony & 25 & Antagony \\
\hline K. pneumoniae 3 & 25 & Synergy & 20 & Antagony & 22 & Synergy & 6 & Antagony \\
\hline K. pneumoniae 4 & 18 & Antagony & 34 & Synergy & 28 & Synergy & 6 & Antagony \\
\hline Enterobacter & 13 & Antagony & 10 & Antagony & 7 & Antagony & 6 & Antagony \\
\hline MRSA 1 & 12 & Indifferent & 32 & Synergy & 9 & Antagony & 15 & Synergy \\
\hline MRSA 2 & 13 & Synergy & 43 & Synergy & 13 & Antagony & 26 & Synergy \\
\hline MRSA 3 & 12 & Antagony & 28 & Antagony & 8 & Antagony & 18 & Synergy \\
\hline
\end{tabular}

Table.6 Inhibition zone of the prepared combination

\begin{tabular}{|l|l|l|l|}
\hline Organism & $\begin{array}{l}\text { Ps. } \\
\text { aeruginosa }\end{array}$ & MRSA & $\begin{array}{l}\text { Comb. } \\
\text { Action }\end{array}$ \\
\hline Algae extract & 6 & 6 & - \\
\hline Amikacin & 17 & 13 & - \\
\hline Ag+ & 10 & 15 & - \\
\hline $\begin{array}{l}\text { Extract }+ \\
\text { Amikacin }\end{array}$ & 33 & 32 & Synergy \\
\hline $\begin{array}{l}\text { Extract }+ \\
\text { Ag+ }\end{array}$ & 37 & 22 & Synergy \\
\hline $\begin{array}{l}\text { Amikacin }+ \\
\text { Ag+ }\end{array}$ & 38 & 29 & Synergy \\
\hline Combination & 40 & 35 & Synergy \\
\hline
\end{tabular}


Table.7 Retention time (rt) and probable compounds according to MS library

\begin{tabular}{|c|c|c|}
\hline RT & Probable compound & Area \% \\
\hline $\mathbf{9 . 6}$ & Decane, 2,3,5,8-tetramethyl (acyclic alkanes) & 6.2 \\
\hline $\mathbf{1 5 . 7}$ & Benzeneacetic acid, 4-pentadecyl ester (monocyclic phenolic acids) & 5.8 \\
\hline $\mathbf{1 7 . 0 1}$ & Eicosane, 2-methyl (alkane) & 7.2 \\
\hline $\mathbf{1 7 . 7}$ & Heptadecane, 2,6,10,15-tetramethyl (alkane) & $\mathbf{1 1 . 4}$ \\
\hline $\mathbf{2 0 . 1}$ & Heptacosane (alkane) & 5.7 \\
\hline $\mathbf{2 5 . 4}$ & Octadecane, 3-ethyl-5-(2-ethylbutyl)(alkane) & 4.0 \\
\hline $\mathbf{2 8 . 5}$ & $\begin{array}{c}\text { Benz[e]azulene-3,8-dione, 3a,4,6a 7,9,10,10a,10b-octahydro-3a,10a- } \\
\text { dihydroxy-5-(hydroxymethyl)-7-(1-hydroxy }\end{array}$ & 6.7 \\
\hline $\mathbf{2 9 . 1}$ & Hexanedioic acid, bis(2-ethylhexyl) ester & 7.4 \\
\hline 30.4 & olean-12-en-3,15,16,21,22,28-hexol & 45.6 \\
\hline
\end{tabular}

The nanosize allowed expansion of the contact surface of $\mathrm{Ag}$ with the microorganisms, and this nanoscale has applicability for medical devices by surface coating agents. In the study of Kim et al., (2007), to evaluate the antimicrobial effects against various microorganisms, they used three representative microorganisms, yeast, E. coli and S. aureus. There were distinct differences among them. When Ag nanoparticles were tested in yeast and E. coli, they effectively inhibited bacterial growth. In contrast, the inhibitory effect of $\mathrm{Ag}$ nanoparticles was mild in $\mathrm{S}$. aureus as compared with other microorganisms; these results suggest that the antimicrobial effects of $\mathrm{Ag}$ nanoparticles may be associated with characteristics of certain bacterial species. Gram-positive and Gram-negative bacteria have differences in their membrane structure, the most distinctive of which is the thickness of the peptidoglycan layer.

The antimicrobial activity AgNP was found to be size dependent, and larger particles are less active than smaller one against many pathogens in both in vitro and in vivo analysis (Alberti et al., 2004; Panacek et al., 2006 and Poulose et al., 2014). The resistance of bacteria towards antibiotics has made AgNPs more effective than antibiotics (Leid et al.,
2012 and Chernousova and Epple, 2013). Though there is plenty of research in AgNPs, the actual mode of action of AgNPs is still unclear (Majdalawieh et al., 2014). In E. coli, the AgNPs create holes in the cell wall and increase the membrane permeability, thereby inactivating the cell activity. Some reports revealed that the $\mathrm{Ag}$ ions disrupt the protein structure by binding to thiol and amino groups (Choi et al., 2008). Kim et al., (2007), think that the lower efficacy of the Ag nanoparticles against $S$. aureus may derive from the difference as a point of membrane structure. The mechanism of the inhibitory effects of Ag ions on microorganisms is partially known. Some studies have reported that the positive charge on the $\mathrm{Ag}$ ion is crucial for its antimicrobial activity through the electrostatic attraction between negative charged cell membrane of microorganism and positive charged nanoparticles (Hamouda et al., 2000). In contrast, Sondi and Salopek-Sondi (2004) reported that the antimicrobial activity of silver nanoparticles on Gram-negative bacteria was dependent on the concentration of Ag nanoparticle, and was closely associated with the formation of dpitsT in the cell wall of bacteria. Then, Ag nanoparticles accumulated in the bacterial membrane caused the permeability, resulting in cell death. Amro et al., (2000) suggested that 
metal depletion may cause the formation of irregularly shaped pits in the outer membrane and change membrane permeability, which is caused by progressive release of lipopolysaccharide molecules and membrane proteins. Also, Sondi and SalopekSondi (2004) speculate that a similar mechanism may cause the degradation of the membrane structure of E. coli during treatment with Ag nanoparticles. Although their inference involved some sort of binding mechanism, still unclear is the mechanism of the interaction between $\mathrm{Ag}$ nanoparticles and component(s) of the outer membrane.

\section{Gas Chromatography-Mass Mass Spectrometry (GC-MS-MS)}

GC-MS-MS analysis of the $U$. fasciata sample extracted with toluene showed five compounds of acyclic and noracyclic sesterterpenoids such as 2,3,5,8-tetramethyldecane (acyclic alkanes), 2 methyleicosane (alkane), 2,6,10,15 tetramethylheptadecane (alkane), heptacosane (alkane) and 3-ethyl-5-(2-ethylbutyl) octadecane, (alkane). In addition to esters such as benzeneacetic acid, 4-pentadecyl ester and hexanedioic acid, bis(2ethylhexyl) ester (ester). Other bioactive compounds such as $3 a, 4,6 a, 7,9,10,10 a, 10 b$-octa hydro3a,10adihydroxy-5-(hydroxy methyl)-7-(1hydroxy-1methylethyl)-2,10-dimethyl benz[e] azulene-3,8dione, pentacyclic triterpenoid (Oleanolic acid) and carotenoid (tetrahydrospirillo xanthin), and benzenepropanoic acid (Figure 22, Table 7). In order to determine the bioactive component in the sample, column chromatography was performed for the crude $U$. fasciata toluene extract followed by antibacterial assay for the collected fractions which indicated one of the separated fractions as the active fraction (Figure 23).

Further GC-MS-MS analysis of the active fraction was performed (Figures 23, 24).
According to the GC-MS-MS database the predicted structure of the isolated active compound was that of compound: olean-12en-3, 15, 16, 21, 22, 28-hexol, with probability only $91.17 \%$. This indicates that the isolated compound could be an isomer of the suggested compound.

Further GC-MS-MS analysis of the active fraction was performed (Figures 24). The analysis indicated the presence of olean-12en-3, 15, 16, 21, 22, 28-hexol as a major component, in the active fraction

Chandrasekaran et al., 2014 reported that the ethyl acetate extract of the $U$. fasciata showed the presence of phytochemicals, terpenoids, tannins and phenolic compounds. Paulraj, (2010) reported earlier the isolation of five sesquiterpens from methanol extract of $U$. fasciata 2,5,5-trimethyl-4-(4-methyl3pentenyl)-2-cycloexen-1-ol, 4-isopentyl-3, 4, 5 , 5 tetramethyl-2- cyclohexen-1-ol, two diastereoisomeric compounds), 6-isopentyl1,5,5,6- tetramethyl-1-cyclohexene, and 3,4,5,5-tetramethyl 4-(3/-oxopentyl)-2-cyclohexen-1-one. In addition to, Two guaiane sesquiterpene derivatives, viz., guai-2en-10aol and guai-2-en-10a-methanol.Horiuchi et al., (2007) found that an extract from Salvia officinalis (Sage) leaves showed antimicrobial activity against vancomycin-resistant enterococci (VRE). They isolated the effective compound and identified it as oleanolic acid, a triterpenoid which also showed antimicrobial activity against Streptococcus pneumoniae and methicillinresistant Staphylococcus aureus (MRSA).

According to the previous reported studies and our results, one can conclude that probably our isolated compound is a derivative of oleanolic acid. The possible structure of the suggested compound could be the penta-hydroxy derivative of oleanolic acid (Figure 26). The molecular weight of the suggested compound (Mwt: 536) is in 
accordance with the Mass Spectrum $(\mathrm{M}-2 \mathrm{H})$ $+=534)$.

Toluene extract of $U$. fasciata has the highest activity through this study and it considered as eco-friendly and completely safe. Combination between algal extract plus amikacin showed significant increase in the inhibition zone. Synergistic action was noticed between the silver nanoparticles (green synthesized by the $U$. fasciata extract) + amikacin (as known antibiotic) and $U$. fasciata extract (as the natural product). The effect of amikacin was increased 1.5 times, the silver nanoparticles increased 4 times and the algal extract increased 4.5 times. This synergy means less toxicity, less side effects and less cost. The synergistic effect may be due to certain complex formation which becomes more effective in the inhibition of a particular species of microorganisms either by inhibiting the cell wall synthesis or by causing its lysis or death. It is reasonable to use combination therapy in order to achieve bactericidal synergism. Such combinations i.e. association of antibiotics with natural extracts against resistant bacteria will have different mechanisms of action and it may lead to new choices for the treatment of infectious diseases. Combination therapy can be used to expand the antimicrobial spectrum, to prevent the emergence of resistant mutants, to minimize toxicity, thereby exhibiting antimicrobial activity greater than that would be expected from each antimicrobial drug individually. The potential benefits of using combined antimicrobial therapy can be treatment of mixed infections, therapy of severe infections in which a specific causative organism is known, enhancement of antibacterial activity and reducing the time needed for long- term antimicrobial therapy. GC-MS-MS analysis of the $U$. fasciata sample showed Acyclic and noracyclic sesterterpenoid, pentacyclic triterpenoid, esters and carotenoid and the isolated active compound was olean-12-en3, 15, 16, 21, 22, 28 -hexol, with probability only $91.17 \%$ so probably our isolated compound is a derivative of oleanolic acid.

\section{References}

Abd El Aal A., El-Hadidy M., ElMashad N., El-Sebaie A. Antimicrobial effect of bee honey in comparison to antibiotics on organisms isolated from infected burns. 2007. Ann. Burns Fire Dis. 20:83.

Alberti S., Böhse K., Arndt V., Schmitz A. and Höhfeld J. The cochaperone HspBP1 inhibits the CHIP ubiquitin ligase and stimulates the maturation of the cystic fibrosis transmembrane conductance regulator. 2004. Mol. Biol. Cell.

Amro N.A., Kotra L.P., Wadu-Mesthrige K., Bulychev A., Mobashery S. and Liu G. High-resolution atomic force microscopy studies of the Escherichia coli outer membrane: structural basis for permeability. 2000. Langmuir.

Amy L.R. Zebrafish assays for drug toxicity screening. 2006. Ashley

Antibacterial activity of Ulva fasciata against Multidrug Resistant Bacterial Strains. 2014. Inter. Let. Nat. Sci. Online: ISSN: 2300-9675. 19: 40-51. doi:10.18052/www.scipress.com/ILNS. 19. 40. SciPress Ltd., Switzerland 11. Chattopadhyay S.K. and Satyanshu K.A. Rapid Liquid ChromatographyTandem Mass Spectrometry Method for Antimicrobial and hemolytic activity of seaweed extracts Ulva fasciata (Delile 1813) from Mandapam, Southeast coast of India. 2011 Asi. Paci. J. Trop Biomed. 1(1):S38-S39.

Atasever-Arslan B., Yilancioglu K., Zeynep K., Ahmet C.T., Hazal G., Fatma B.I., Emre D., Batu E. and Selim C. Screening of New Antileukemic Agents from Essential Oils of Algae Extracts 
and Computational Modelling of Their Interactions with Intracellular Signalling

Baquero F., Martínez J.L. and Cantón R. Antibiotics and antibiotic resistance in water environments. 2008. Curr Opin Biotechnol. 19(3):260-265.

Borowitzka M.A. High-value products from microalgae - their development and commercialization. 2013. J. Appl. Phycol. 25:743-756.

C.L., Yun Y.H., Youngs W.J., Seckinger N.M. and Cope E.K. In vitro antimicrobial studies of silver carbene complexes: activity of free and nanoparticle carbene formulations against clinical isolates of pathogenic bacteria. 2012. J. Antimicrob. Chemother. 67(1):138-148.

Chakraborty K., Lipton A., Paulraj P., Rekha R., Chakraborty D. 2010. Euro. J. Med. Chem. 45:2237-2244.

Chandrasekaran M., Venkatesalu V., Adaikala Raj G. and Krishnamoorthy S. Antibacterial activity of Ulva fasciata against Multidrug Resistant Bacterial Strains. 2014. Inter. Let. Nat. Sci. Online. 19:40-51.

Chandrasekaran M., Venkatesalu V., Adaikala Raj G. and Krishnamoorthy S. Chernousova S. and Epple M. Silver as antibacterial agent: ion, nanoparticle, and metal. 2013. Angew. Chem. Int. Ed. 52(6):1636-1653.

Choi O., Deng K.K., Kim N.J., Ross L. Jr., Surampalli R.Y. and $\mathrm{Hu}$ Z. The inhibitory effects of silver nanoparticles, silver ions, and silver chloride colloids on microbial growth. 2008. Water Res. 42(12):3066-3074.

Davis S.A., Patel H.M., Mayes E.L., Mendelson N.H., Franco G. and Mann S. Brittle bacteria: a biomimetic approach to the formation of fibrous composite materials. 1998. Chem. Mater. 10:2516- 2524.
Felix Lewis Oscar, Sasikumar Vismaya, Fon Sing S., Isdepsky A., Borowitzka M.A. and Moheimani N.R. Production of biofuels from microalgae. 2013. Mitig Adapt Strateg Glob Chang 18: 47-720.

Giske C.G., Monnet D.L., Cars O and Carmeli Y. Clinical and economic impact of common multidrug-resistant gramnegative bacilli. 2008. Antimicrob Agents Chemother. 52(3):813-821.

Gonz.lez del Val A., Platas G. and Basilio A. Screening of antimicrobial activities in red, green and brown macroalgae from Gran Canaria (Canary Islands, Spain). 2001. Int. Microbiol. 4:3540.

Guerra-Rivas G., Mariana GomezGutierrez C., Alarcon-Arteaga G., Esthela SoriaMercado I. and Ernestina AyalaSanchez N. Screening for anticoagulant activity in marine algae from the Northwest Mexican Pacific coast. 2011. J. Appl. Phycol. 23:495- 503.

Hamouda T., Myc A., Donovan B., Shih A., Reuter J.D. and Baker J.J.R. A novel surfactant nanoemulsion with a unique non-irritant topical antimicrobial activity against bacteria, enveloped viruses and fungi. 2000. Microbiol. Res. 156:1-7.

Horiuchi K., Shiota S., Hatano Ibñez E. and Cifuentes A. Benefits of using algae as natural sources of functional ingredients. 2013. J. Sci. Food Agric. 93:703-709.

Johansen MN (ed) (2011). Microalgae: biotechnology, microbiology and energy. New York: Nova Science.

Kellogg J. and Lila, M.A. Chemical and in vitro assessment of Alaskan coastal vegetation antioxidant capacity. 2013. J. Agric. Food Chem. 61:11025-11032.

Kim J.S., Eunye K., Kyeong N.Y., Jong- Ho K., Sung J.P., Hu Jang L., So Hyun K., Young Kyung P., Yong Ho P., CheolYong H., Yong-Kwon K., Yoon-Sik L., Dae Hong J. and Myung-Haing C. 
Antimicrobial effects of silver nanoparticles. $2007 . \quad$ Nanomed. Nanotech. Bio. Med. 3:95-101.

Kone W.M., Kamanzi Atindehou K., Terreaux C., Hostettmann K., Traore D. and Dosso, M. Traditional medicine in North Cote-d'Ivoire screening of 50 medicinal plants for antibacterial activity. 2004. J. Ethnopharmacol. 93:43-49.

Lee R. 2008. Phycology. Cambridge: Cambridge University Press.

Leid J.G., Ditto A.J, Knapp A., Shah P.N., Wright B.D., Blust R., Christensen L., Clemons C.B., Wilber J.P., Young G.W., Kang A.G., Panzner M.J., Cannon C.L., Yun Y.H., Youngs W.J., Seckinger N.M. and Cope E.K. In vitro antimicrobial studies of silver carbene complexes: activity of free and nanoparticle carbine formulations against clinical isolates of pathogenic bacteria. 2012. J. Antimicrob. Chemother. 67(1):138-148.

Lingchong W., Xiangyu W., Hao W. and Rui L. Overview on Biological Activities and Molecular Characteristics of Sulfated Polysaccharides from Marine Green Algae in Recent Years. 2014. Mar. Drugs. 12(9):4984-5020.

Majdalawieh A., Kanan M.C., El-Kadri O. and Kanan S.M. Recent advances in gold and silver nanoparticles: synthesis and applications. 2014. J. Nanosci. Nanotechnol. 14(7):4757-4780.

Maryann H., Maegan H., Louis D'A., Anthony DeL. and Wen Lin S. Zebrafish: Methods for Assessing Drug Safety and Toxicity, Edited by Patricia McGrath. 2012. John Wiley \& Sons, Inc. Ch.2 Devel. Tox. Assess. Zebrafish. Pp. 15-25.

Maryann H., Maegan H., Louis D'A., Anthony DeL. and Wen Lin S. Zebrafish: Methods for Assessing Drug Safety and Toxicity, Edited by Patricia
McGrath. 2012. John Wiley \& Sons, Inc. Ch.2Devel. Tox. Assess. Zebrafish. Pp. 15-25.

McDowell and Trump, (1976)

Panacek A., Kvítek L., Prucek R., KolarM., Vecerova R., Pizúrova N., Sharma V.K., Nevecna T. and Zboril R. Silver colloid nanoparticles: synthesis, characterization, and their antibacterial activity. 2006. J. Phys. Chem. 110(33): 16248-16253.

Park N.H., Choi J.S., Hwang S.Y., Kim Y.C., Hong Y.K., Cho K.K. and Choi, I.S. Antimicrobial activities of stearidonic and gamma-linolenic acids from the green seaweed Enteromorpha linza against several oral pathogenic bacteria. 2013. Bot. Stud. 54(39).

Paz E.A., Cerdeiras M.P., Fernandez J., Ferreira F., Moyna P., Soubes M., Vazquez A., Vero S. and Zunino L. 1995. J. Ethnopharm. 45:67-70.

Poulose S., Panda T., Nair P.P. and Th'eodore T. 2014. Biosynthesis of silver nanoparticles. J. Nanosci. Nanotechnol. 14(2): 2038-2049.

Priyadharshini S., Bragadeeswaran S., Prabhu K. and Sophia Ran S. 2011. Antimicrobial and hemolytic activity of seaweed extracts Ulva fasciata (Delile 1813) from Mandapam, Southeast coast of India. Asi. Paci. J. Trop Biomed. 1(1): S38-S39.

Rajesh S., Raja D.P., Rathi J.M. and Sahayaraj K. 2012. Biosynthesis of silver nanoparticles using Ulva fasciata (Delile) ethyl acetate extract and its activity against Xanthomonas campestris pv. Malvacearum. J. Biopestic. 5: 119-128.

Sahayara K., Rajesh S. and Rathi J. M. Silver Nanoparticles Biosynthesis Using Marine Alga Padina pavonica (LINN.) and its Microbicidal Activity. 2012. Dig. J. Nano. Biostr. 7(4):1557-1567.

Say P.J., Burrows I.G. and Whitton B.A. 
Enteromorpha as a Monitor of Heavy Metals in Estuarine and Coastal Intertidal Waters: A Method for the Sampling, Treatment and Analysis of the Seaweed Enteromorpha to Monitor Heavy Metals in Estuaries and Coastal Waters. 1986. Nor. Env. Cons. Ltd.: Durham, UK, 8-9.

Selvin J. and Lipton A.P. 2004. J. Marine Sci. Tech. 12:1-6.

Senthilkumar P., Durga Devi V., Minhajdeen A., Saranya R.S., Sree Jaya S. and Sudha S. Antibacterial Properties of Enteromorpha flexuosa (Wulfen) from the Gulf of Mannar Southeast Coast of India. 2014. Amer. J. Ethnomed. 1(1):50-55.

Shan B., Cai Y.Z., Brooks J.D. and Corke H. 2007. Inter. J. Food Microbiol. 117:112-119.

Sharma A, Sharma S, Sharma K, Chetri SPK, Vashishtha A, Singh P, Kumar R, Rathi B, Agrawal V (2015). Algae as crucial organisms in advancing nanotechnology: a systematic review. $J$. Appl. Phycol., 2014: 1-16. doi:10.1007/s 10811-015-0715-1.

Sondi I. and Salopek-Sondi B. Silver nanoparticles as antimicrobial agent: a case study on E. coli as a model for Gram negative bacteria. 2004. $J$. Colloid. Interface Sci. 275(177):82.

Sukatar A., Karabay-Yavasoglu N.U., Ozdemir G. and Horzum Z. Antimicrobial activity of volatile component and various extracts of Enteromorpha linza (Linnaeus) J. Agardh from the coast of Izmir, Turkey.
2006. Anal. Microbiol. 56:275-279.

Sumitra C. and Kalpna R. Combination therapy: Synergism between natural plant extracts and antibiotics against infectious diseases Science against microbial pathogens: communicating current research and technological advances. 2011. Méndez-Vilas A. (Ed.). Pp. 520-529.

T., Yoshida T., Kuroda T. and Tsuchiya T. Antimicrobial activity of oleanolic acid from Salvia officinalis and related compounds on vancomycin-resistant enterococci (VRE). 2007. Biol Pharm Bull. 30(6):1147-1149.

Taskin E., Ozturk M., Kurt O. 2001. Afri. J. Biotech. 6:2746-2751.

Thajuddin, Dharumadurai Dhanasekaran and Chari Nithya. 2016. Algal Nanoparticles: Synthesis and biotechnological potentials. Nooruddin Thajuddin and Dharumadurai Dhanasekaran (Eds). doi: 10.5772/62909

Yoshihiro S., Tadashi T., Tomohiro K. and Katsuhiko M. Isolation of an allelopathic substance from the crustose coralline algae, Lithophyllum spp., and its effect on the brown alga, Laminaria religiosa Miyabe (Phaeophyta). 1998. J.

Young Kyung P., Yong Ho P., CheolYong H., Yong-Kwon K., Yoon-Sik L., Dae Hong J. and Myung-Haing C. Antimicrobial effects of silver nanoparticles. 2007. Nanomed. Nanotech. Bio. Med. 3:95-101.

\section{How to cite this article:}

Elnahas, R.A., R. Salem, R. Dorgham, A. Elmorsy, B. Elwakil, S. Khattab and Olama, Z. 2017. Algal Bioactive Metabolites against MDR Bacteria. Int.J.Curr.Microbiol.App.Sci. 6(9): 255279. doi: https://doi.org/10.20546/ijcmas.2017.609.034 